\title{
Synthesis, characterization and a reactivity study of some allyl palladium complexes bearing bidentate hemi-labile carbene or mixed carbene/ $\mathrm{PPh}_{3}$ ligands
}

\author{
L. Canovese ${ }^{\text {a,* }}$, F. Visentin ${ }^{\text {a }}$, T. Scattolin ${ }^{\text {a }}$, C. Santo ${ }^{\text {a }}$, V. Bertolasi ${ }^{\text {b }}$ \\ ${ }^{a}$ Dipartimento di Scienze Molecolari e Nanosistemi, Università Ca' Foscari, Venice, Italy \\ ${ }^{\mathrm{b}}$ Dipartimento di Scienze Chimiche e Farmaceutiche, Università di Ferrara, Ferrara, Italy
}

\section{A R T I C L E I N F O}

\section{Article history:}

Received 8 August 2016

Accepted 31 August 2016

Available online 15 September 2016

Keyword:

Allyl palladium complexes

\begin{abstract}
A B S T R A C T
With the aim at synthesizing novel allyl complexes that can potentially act as catalysts in the Tsuji-Trost catalyzed reaction, we have synthesized and characterized some allyl and 2-Meallyl palladium derivatives with one hemilabile bidentate or two strong mono-coordinating spectator ligands. The hemilabile ligands are constituted by one nitrogen heterocyclic carbene (NHC) fragment acting as the pivot bearing a labile wing with a pyridine nitrogen or sulfur atom as the second stabilizing atom. One of two monodentate ligands is in all cases $\mathrm{PPh}_{3}$ whereas the other is a mono- or partially coordinated hemilabile carbene. The complexes were characterized by standard spectroscopic methods and elemental analysis and in two cases by SC-XRD technique.

The reactivity of two selected complexes toward the Tsuji-Trost reaction was tested by stoichiometric allyl amination carried out with piperidine and the results of such a mechanistic investigation integrated by a computational study are also reported in this paper.
\end{abstract}

(c) 2016 Elsevier Ltd. All rights reserved.

\section{Introduction}

Since their discovery [1] and the synthesis of the first stable derivatives [2], NHC ligands have been recognized as the real alternative to phosphines in the preparation of stable palladium catalysts [3]. This is mainly due to their low toxicity, their stability toward heat, moisture and air [4] and to the easy tune-up of the steric hindrance of the substituents at the imidazolic nitrogen [5]. However, beside the stability, catalysts should be also characterized by a remarkable reactivity which may be often depressed by the strong $\sigma$-donor capability of the NHC ligands in the case of reactions involving nucleophilic attack to coordinated molecules or to the metal itself. A possible solution overcoming these chemically conflicting features might be the use of hemilabile ligands [6]. The labile terminus should be easily displaced making accessible a site in the coordination sphere, while the stability of complexes should be warranted by the pivot, which represents the

\footnotetext{
* Corresponding author.

E-mail address: cano@unive.it (L. Canovese).
}

strong coordinating part of the ligands [7]. The dangling labile nucleophile plays an important role as well, since it will eventually restore the starting complexes by re-coordinating the site made vacant after release of the final organic substrates [8].

Owing to the importance of this sort of ligands $[5 \mathrm{~g}, 6 \mathrm{r}-\mathrm{w}, 9]$, in order to enlarge the family of hemilabile palladium allyl complexes, we have synthesized some new allyl and 2-Meallyl palladium complexes bearing as spectator ligands heteroditopic carbene ligands bearing pyridine or thioetheric sulfur as labile terminus. For the sake of completeness and comparison, we have also prepared some palladium allyl and 2-Meallyl complexes bearing a mono- or bis-chelate carbene and diphenylphosphine. Finally, we have measured the accessible reaction rates of two different palladium allyl derivatives with piperidine since the nucleophilic attack of an amine at the coordinated allyl moiety is considered the key step in the palladium-catalyzed allyl amination [10]. Moreover, such a detected reactivity may be of interest since it can be easily compared with previously determined rate constants including NHC-phosphine [5a], $\boldsymbol{\alpha}$-diimine [11], pyridyl-thioether [12], and phosphoquinoline [13] palladium allyl derivatives. The synthesized ligands and complexes used in this work are reported in the following Scheme 1. 


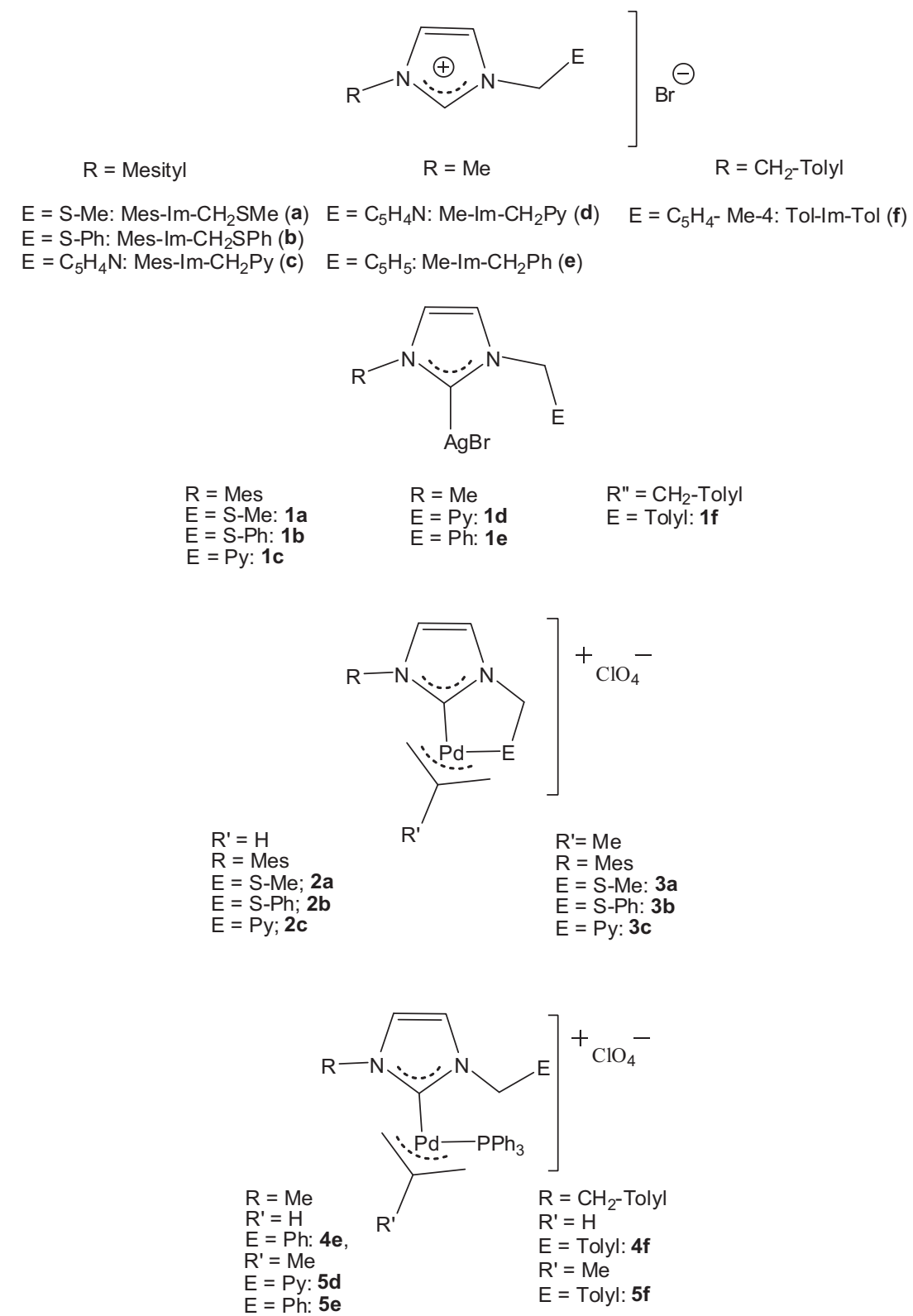

Scheme 1. Imidazolium salts and related silver and palladium allyl complexes.

\section{Results and discussion}

\subsection{General remarks}

The ligands Mes-Im- $\mathrm{CH}_{2} \mathrm{SMe}$ (a) [6v], Mes-Im- $\mathrm{CH}_{2} \mathrm{SPh}$ (b) [14], Mes-Im- $\mathrm{CH}_{2} \mathrm{Py}(\mathbf{c}), \mathrm{Me}-\mathrm{Im}-\mathrm{CH}_{2} \mathrm{Py}$ (d) [15], Me-Im- $-\mathrm{CH}_{2} \mathrm{Ph}(\mathbf{e})$ [5h], the complexes 1a, 2a [16], 1b, 1c, 1d, [14], 1e [5h], the dimers $\left[\mathrm{Pd}(\mu-\mathrm{Cl})\left(\eta^{3}-\mathrm{C}_{3} \mathrm{H}_{5}\right)\right]_{2}[17]$ and $\left[\mathrm{Pd}(\mu-\mathrm{Cl})\left(\eta^{3}-2-\mathrm{MeC}_{3} \mathrm{H}_{4}\right)\right]_{2}[18]$ were synthesized according to published protocols.

\subsection{Palladium allyl complexes}

The allyl complexes shown in Scheme 1 were successfully synthesized in high yield and purity by silver-mediated transmetallation of the carbenic ligand to palladium in $\mathrm{CH}_{2} \mathrm{Cl}_{2}$ [19].

Thus, the new complexes $\mathbf{2 b}-\mathbf{c}, \mathbf{3 a}-\mathbf{c}, \mathbf{4 e - f}$ and $\mathbf{5 d}-\mathbf{f}$ were obtained by reacting a stoichiometric amount of the appropriate silver complex 1 with the dimers $\left[\mathrm{Pd}(\mu-\mathrm{Cl})\left(\eta^{3}-\mathrm{C}_{3} \mathrm{H}_{5}\right)\right]_{2}$ or $\left[\mathrm{Pd}(\mu-\mathrm{Cl})\left(\eta^{3}-2-\mathrm{MeC}_{3} \mathrm{H}_{4}\right)\right]_{2}$, as reported in Scheme 2 .

As shown in Scheme 2 both reactions yielding complexes 2 and $\mathbf{3}$ and complexes $\mathbf{4}$ and $\mathbf{5}$ involve two independent steps. The first common step provides an intermediate bearing the carbene NHC, the allyl and chloride coordinated to the metal which reverts into derivatives 2 and 3 upon dechloridation with $\mathrm{NaClO}_{4}$. All the ensuing complexes were obtained in this case in reasonable yield (70-90\%) and are characterized by a heteroditopic five- or sixmembered chelate ring (complexes $\mathbf{2 c}$ and $\mathbf{3 c}$ ) bearing a carbenic carbon and sulfur or nitrogen as coordinating atoms, respectively. The synthesis of complexes $\mathbf{4}$ and $\mathbf{5}$ entails the contemporary addition of $\mathrm{NaClO}_{4}$ and a stoichiometric amount of $\mathrm{PPh}_{3}$ to the intermediates. In any case the precipitation of $\mathrm{NaCl}$ which is insoluble in the solvent mixture $\left(\mathrm{CH}_{2} \mathrm{Cl}_{2} / \mathrm{MeOH}: 3 / 1, \mathrm{v} / \mathrm{v}\right)$ indicates the formation in solution of the allyl complexes. Notably, coordination of the phosphine is complete even in the case of complexes bearing the ligand Me-IM- $\mathrm{CH}_{2} \mathrm{Py}$. 


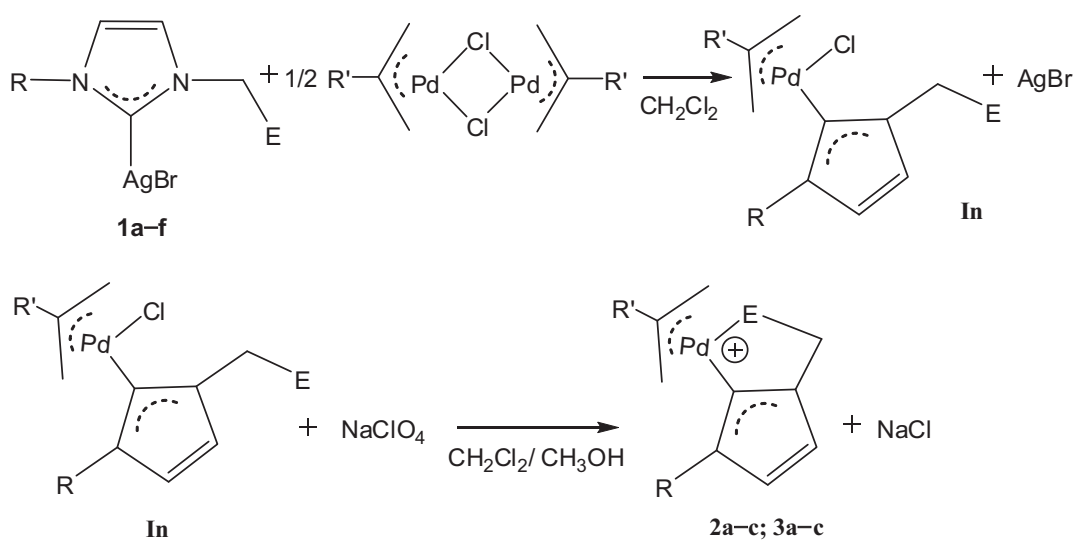

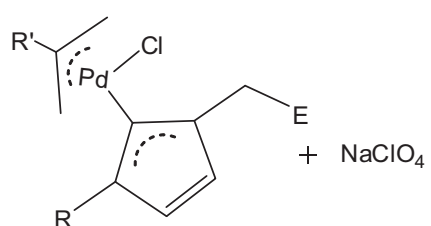

In

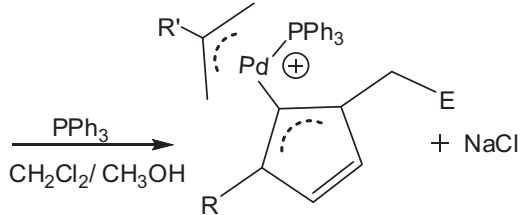

$4 e-f ; 5 d-f$

Scheme 2. Synthesis of palladium(II) allyl complexes.

\subsection{Characterization of palladium(II) allyl complexes bearing bidentate spectator ligands}

The characterization of the newly synthesized complexes was carried out by NMR, IR and elemental analysis (see Experimental section for details).

In particular, the RT ${ }^{1} \mathrm{H}$ NMR spectra of all the synthesized complexes are of interest. Owing to the ditopicity of the ancillary ligands and the coordination mode of the allyl fragment almost perpendicular to the main plane of the complex, all the ensuing compounds belong to the $C_{1}$ symmetry group. Accordingly, the $\mathrm{R}-\mathrm{Im}-\mathrm{CH}_{2} \mathrm{Py}$ or R-Im- $\mathrm{CH}_{2} \mathrm{SR}$ methylene protons are detected as an A-B signal owing to their proximity to the chiral palladium. Moreover, the complexes $\mathbf{2 c}$ and $\mathbf{3 c}$ might generate two isomers (and the related enantiomers) characterized by the mutual position of the central allyl substituent and the methylene fragment out of the main coordination plane between the carbene and the pyridine moiety of the spectator ligand. (See Section 2.6 and Scheme 3. See also Supplementary material Scheme 1SM.)

The interconversion among isomers can be promoted by the up and down conformational movement of the $\mathrm{R}-\mathrm{Im}-\mathrm{CH}_{2} \mathrm{Py}$ unit, by $\eta^{3}-\eta^{1}-\eta^{3}$ rearrangement of the allyl ligand or alternatively, by apparent allyl rotation due to the decoordination of the labile term of the spectator ligand, its rotation, and final re-coordination [12].
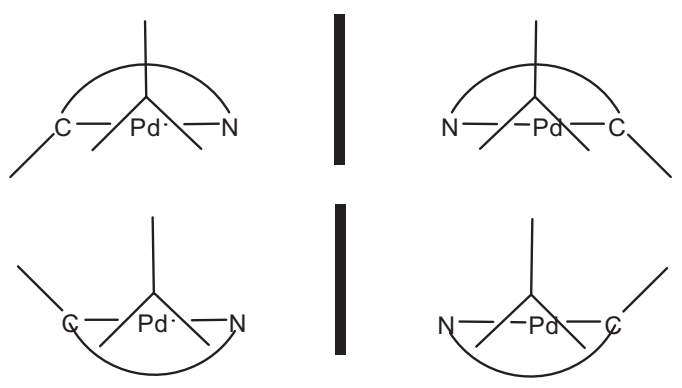

1

Scheme 3. Topological representations of the isomeric distribution of complexes $2 \mathbf{c}$ and $3 c$.
However, since the ${ }^{1} \mathrm{H}$ NMR spectra of the complexes $\mathbf{2 c}$ and $\mathbf{3 c}$ recorded at RT display four distinct signals ascribable to the four terminal syn and anti allyl protons (no $\eta^{3}-\eta^{1}-\eta^{3}$ rearrangement or apparent allyl rotation are operative), we surmise that only the conformational movement of the coordinated $\mathrm{N}-\mathrm{CH}_{2}-\mathrm{C}$ unit is operative and fast with respect to the NMR acquisition time and hence only one set of signals becomes detectable (Supplementary material Fig. 1SM).

As for the 2a-b and 3a-b derivatives, owing to the presence of two potential chiral centers ( $\mathrm{Pd}$ and $\mathrm{S}$ ) and the bent R-Im- $\mathrm{CH}_{2} \mathrm{SR}$ coordinated unit, four isomers and the related NMR undetectable enantiomers should be present in solution (Supplementary material Scheme 2SM).

Again, only one species is observable in the ${ }^{1} \mathrm{H}$ NMR spectra recorded at RT suggesting a general fluxional rearrangement involving the up and down conformational movement of $\mathrm{R}$-Im- $\mathrm{CH}_{2} \mathrm{SR}$ and the fast inversion of the sulfur absolute conformation [12]. Also in this case, no hint of $\eta^{3}-\eta^{1}-\eta^{3}$ rearrangement nor apparent rotation of the allyl ligand are detectable, as can be seen from the multiplet related to the central allyl proton coupled with the four different terminal ones resonating as four independent signals (Supplementary material Fig. 2SM).

Remarkably, in the case of the complexes $\mathbf{2 a - b}$ and $\mathbf{3 a - b}$, no rotation of the mesitylene group is allowed as can be deduced from their ${ }^{1} \mathrm{H}$ NMR spectra which display in any case two different signals ascribable to the ortho methyl groups of the mesitylene fragment (Supplementary material Figs. 1SM and 2SM).

As for the ${ }^{13} \mathrm{C}$ NMR characterization of the complexes it is noteworthy that:

(i) The allyl terminal carbons trans to carbene resonate at lower field than those trans to sulfur (10-14 ppm) and to pyridine nitrogen (ca. $25 \mathrm{ppm}$ ), testifying the higher trans-influence of the carbene with respect to sulfur or nitrogen donor atoms [20].

(ii) The carbons of the ortho methyl groups of the mesitylene are still distinguishable, testifying the hindered rotation of the organic fragment (Supplementary material Figs. 3SM and 4SM). 
(iii) The palladium coordinated carbene carbons resonate at 175-180 ppm (Supplementary material Fig. 5SM).

Finally, the IR spectra of the complexes display the typical strong peaks of the perchlorate at ca. 1090 and $620 \mathrm{~cm}^{-1}$, confirming the ionic nature of the species.

\subsection{Characterization of palladium(II) allyl complexes bearing mixed C-P spectator ligands}

The coordinative characteristics of the allyl palladium complexes bearing $\mathrm{PPh}_{3}$ and the symmetrically substituted imidazole Tol-Im-Tol (4f and $\mathbf{5 f}$ ) can be easily confirmed by both the ${ }^{31} \mathrm{P}$ NMR spectra which display a single peak at lower field than that characterizing the uncoordinated $\mathrm{PPh}_{3}(\Delta \delta \approx 35 \mathrm{ppm})$ and the ${ }^{1} \mathrm{H}$ NMR spectrum displaying a different multiplicity of the terminal allyl protons cis or trans to phosphorus (Supplementary material Fig. 6aSM and 6bSM). The ${ }^{1} \mathrm{H}$ NMR spectra in these cases also suggest that the $\eta^{3}-\eta^{1}-\eta^{3}$ fluxional rearrangement is not operative owing to the clearly observed four distinct signals ascribable to the allyl protons. Moreover, the presence of two A-B systems within 4.5 and 5 ppm related to the $\mathrm{CH}_{2}$-Tol and two Tol- $\mathrm{CH}_{3}$ protons at 2.28 and $2.30 \mathrm{ppm}$ peaks in the ${ }^{1} \mathrm{H}$ NMR spectrum clearly indicates that the vertically coordinated ligand Tol-Im-Tol cannot rotate about the main coordination plane of the complex (Supplementary material Fig. 6bSM; see also Fig. 1 in the Section 2.6). Such a phenomenon confirmed by the ${ }^{13} \mathrm{C}$ NMR spectra in which the albeit small separation between the $\mathrm{CH}_{2}$-Tol and Tol- $\mathrm{CH}_{3}$ carbons is clearly visible (Supplementary material Fig. 6cSM) and by the ${ }^{1} \mathrm{H}$ and ${ }^{13} \mathrm{C}$ NMR of the mixed complexes containing the asymmetric ligands $4 \mathbf{e}$ and $\mathbf{5 d}-\mathbf{e}$. In such case the formation of two atropisomers characterized by the mutual position of the central allyl carbon substituent and one part of the asymmetric ligand with respect to the main coordination plane is unfailingly verified (Supplementary material Fig. 7SM).

\subsection{Kinetic study}

As already stated, in order to deepen our knowledge on the reactivity of different palladium allyl derivatives toward the amination of the allyl fragment we have carried out an investigation on the two complexes $\mathbf{2 a}$ and $\mathbf{2 c}$ which display the appropriate sol- ubility and reactivity when the amination reaction is carried in out at $298 \mathrm{~K}$ with piperidine (Pip) ([Pip]/[Complex] =5/1) in the presence of a small excess of dimethylfumarate (dmfu) ([dmfu]/[Complex $]=1.5 / 1$ ) by ${ }^{1} \mathrm{H}$ NMR technique $[5 \mathrm{a}, 11,13]$.

Owing to the high charge density induced by the strong $\sigma$-donor NHC ligand on the palladium and hence on the allyl moiety, the reactivity of the latter toward nucleophilic attack is low, so that we chose piperidine as the reacting amine. As a matter of fact, piperidine displays the highest nucleophilicity among the amines we have hitherto studied thanks to its high basicity $\left(\mathrm{p} K_{\mathrm{a}}=11.23\right)$ and reduced steric demand [12].

The concentration ratio ([Pip]/([Complex $]=5 / 1$ ) used in our study assures an acceptable reaction rate whereas it is not sufficient for the displacement of the chelating atom $\mathrm{E}$, as confirmed by the ${ }^{1} \mathrm{H}$ NMR spectra. Finally, the dmfu present in solution immediately stabilizes the palladium $(0)$ derivative without interfering with the overall reaction rate law which can be thereby described by the following expression: [11a]

$$
-\frac{d[\text { Allyl Complex }]}{d t}=k_{2}[\text { Allyl Complex }][\text { Pip }]
$$

Non linear regression analysis of the second-order rate law carried out in the ORIGIN ${ }^{\mathrm{TM}}$ environment yields the $k_{2}$ values $(6.9 \pm 0.2) \times 10^{-3}$ and $(5.34 \pm 0.04) \times 10^{-5} \mathrm{~mol}^{-1} \mathrm{dm}^{3} \mathrm{~s}^{-1}$ for $\mathbf{2 a}$ and $\mathbf{2 c}$, respectively. The difference in the reactivity between the complexes is, however, somehow surprising since the coordinative characteristics and the trans-influence of the pyridine nitrogen and the thioetheric sulfur are quite similar and dramatic differences in the allyl amination reaction rates between $\alpha$-diimine and pyridylthioether derivatives have never been observed [11a,12b].

A literature survey [5a,11a,12a,b] confirms that the ligands bearing a NHC fragment, while addressing the amine attack to the allyl carbon trans to carbene, confer to their allyl complexes a reduced reactivity if compared with that of similar species stabilized by $\alpha$-diimine or pyridylthioether ligands. It may be interesting to establish whether in this case also the trans labilized allyl carbon trans to carbene has a higher propensity to the nucleophilic attack than its counterpart trans to nitrogen or sulfur. In this respect, the lower $k_{2}$ value for complex $2 \mathrm{c}$ seems to be due to steric retardation caused by the bulky pyridine, suggesting that the preferred site of the amine attack is at the labilized terminal allyl carbon trans to the carbene. The computational study we have carried

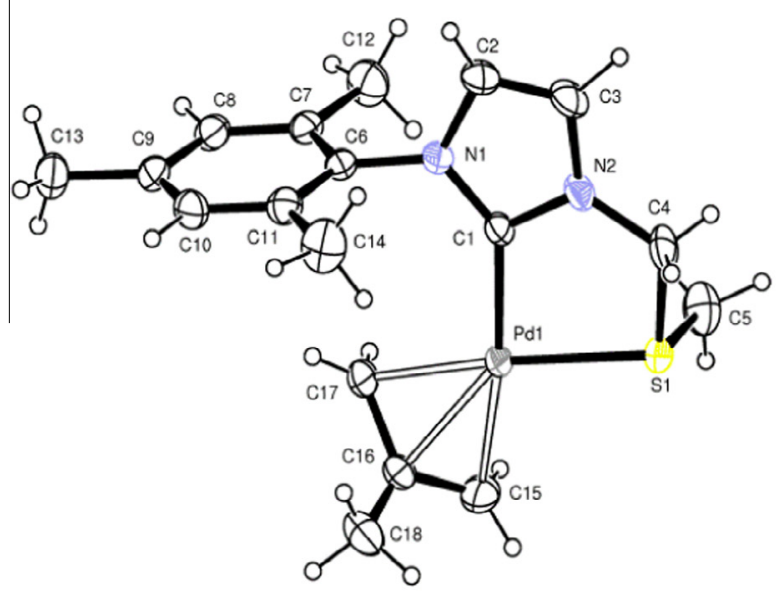

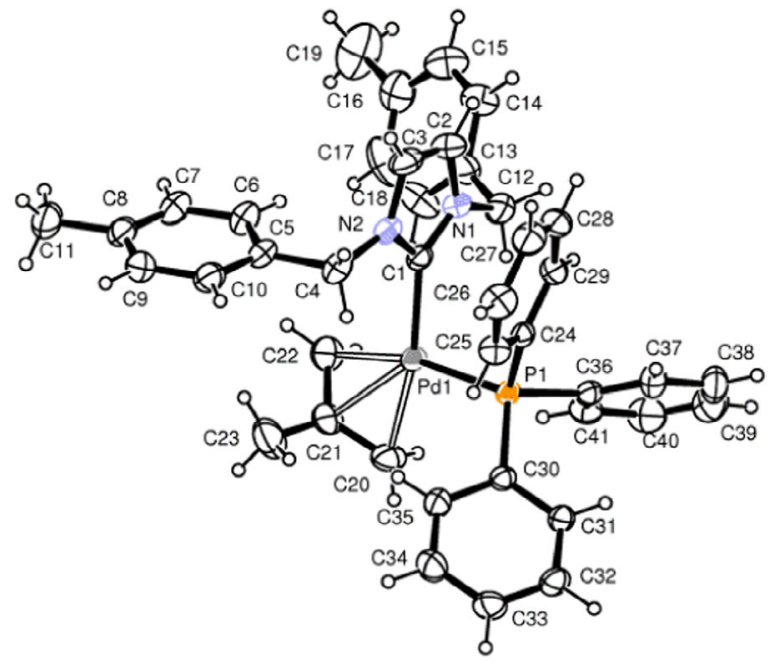

5f

Fig. 1. ORTEP [21] view of cationic complexes 3a (left) and $\mathbf{5 f}$ (right) showing the thermal ellipsoids at $30 \%$ probability level. 

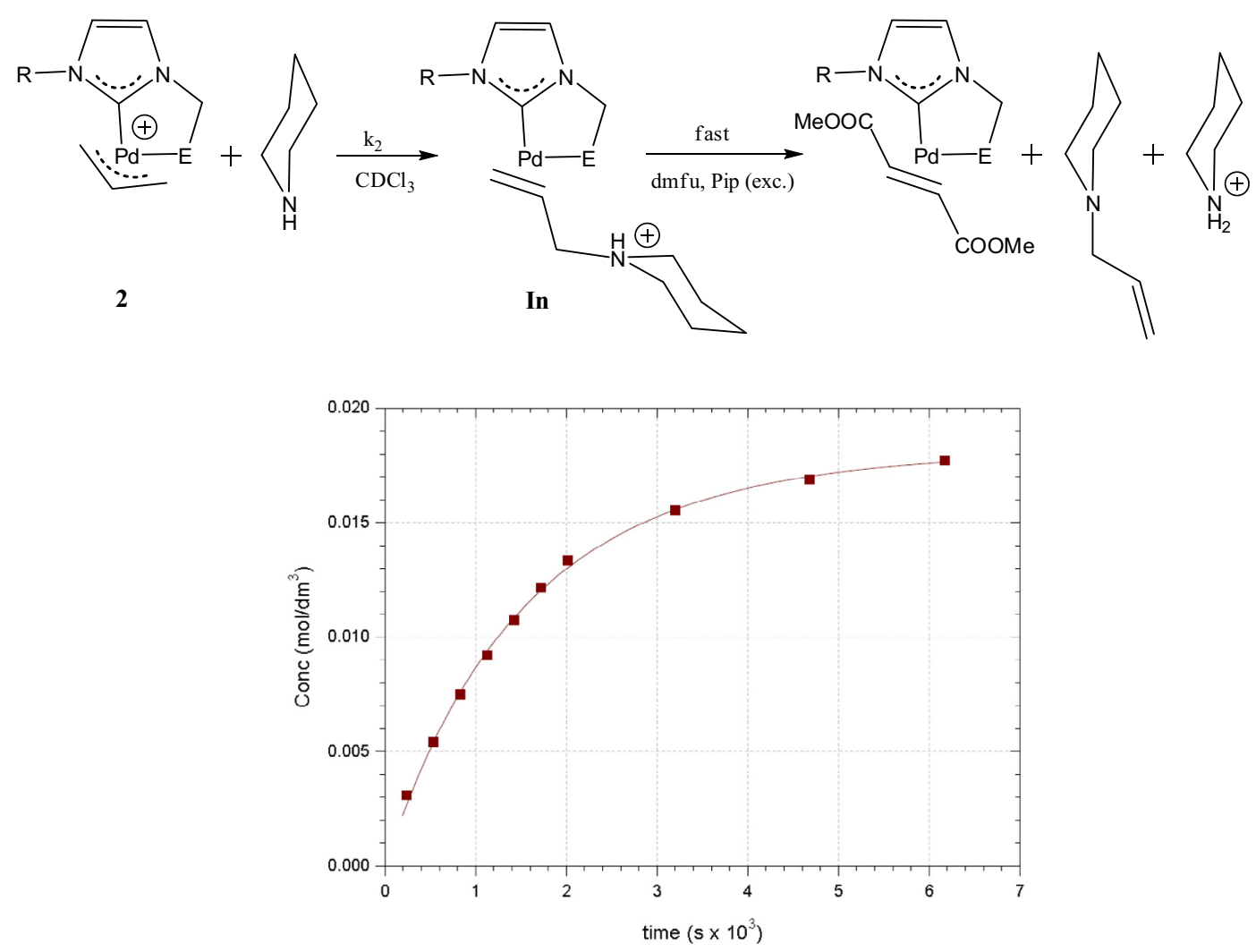

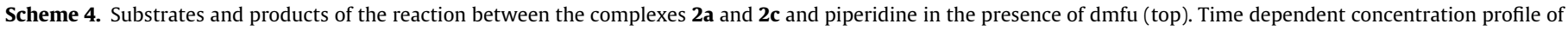
the allylpiperidine product for the reaction between complex $\mathbf{2 a}$ and piperidine in $\mathrm{CDCl}_{3}\left([\mathbf{2 a}]=1.80 \times 10^{-2}\right.$, [pip] $\left.=9.88 \times 10^{-2} \mathrm{~mol} \mathrm{dm}{ }^{-3}\right)($ bottom) .

out confirms our original hypothesis indicating that the attack at the allyl terminus trans to carbene is kinetically preferred in both complexes irrespective of the retardation induced by steric hindrance. The computational results estimated for both reactions considered is summarized in the following Scheme 5 where to save computer time, we have used the simplified complexes $\mathbf{2} \mathbf{a}^{\prime}$ and $\mathbf{2} \mathbf{c}^{\prime}$ bearing a methyl group in place of the mesitylene of the derivatives $\mathbf{2 a}$ and $\mathbf{2 c}$.

The activation enthalpies reported in Scheme 4 confirm that the reactivity of complex $\mathbf{2 a}$ is higher than that of complex $\mathbf{2 c}$, $\left(\Delta H^{\#}{ }_{2 \mathbf{a}}<\Delta H^{\#}{ }_{2 \mathbf{c}}\right)$ and that the attack at the terminal allyl carbon trans to carbene is kinetically favored in both cases $\left(\left(\Delta H^{\#}<\Delta H^{\#}\right)\right.$.

\subsection{Diffractometric study}

ORTEP [21] views of the Pd(II) cationic complexes 3a and 5f are reported in Fig. 1. A selection of bond distances and angles is given in Table 1SM. In complex 3a the palladium is bonded to a dissymmetric NHC bidentate ligand through the carbene carbon and the sulfur atom of the methylthiomethyl $\mathrm{N}$-substituent and $\eta^{3}$-coordinated to the 2-methyl substituted allyl group. The trans effect exerted by the carbene atom can be evidenced by the longer Pd1-C15 distance of 2.180(3) $\AA$ as compared to that where a terminal allyl carbon is in trans position to the sulfur atoms: $\operatorname{Pd} 1-\mathrm{C} 17=2.112(2) \AA$. . In the cationic complex $\mathbf{5 f}$ the palladium is bonded to the carbene carbon of a symmetric NHC ligand, the phosphorus of the triphenylphosphine and $\eta^{3}$-coordinated to the 2-methyl substituted allyl group. The $\mathrm{Pd}-\mathrm{C} 20$ and $\mathrm{Pd}-\mathrm{C} 22$ distances of 2.157(3) A and 2.179(3) Å, respectively, show only a slightly greater trans effect of the $\mathrm{P}(\mathrm{Ph})_{3}$ group with respect to the carbene $\mathrm{C} 1$ carbon.
The 2-Methyl substituted allyl group is rotated with respect to the $\mathrm{Pd}(\mathrm{II})$ basal coordination plane in both cationic complexes forming dihedral angles of $69.3(2)^{\circ}$ and $74.8(2)^{\circ}$ in $\mathbf{3 a}$ and $\mathbf{5 f}$, respectively. The carbene five membered ring is almost coplanar with the Pd(II) basal coordination plane, forming a dihedral angle of $6.56(7)^{\circ}$ in compound 3a, while is almost perpendicular to the $\mathrm{Pd}(\mathrm{II})$ basal coordination plane, forming an angle of $88.72(9)^{\circ}$ in compound $\mathbf{5 f}$.

\section{Conclusions}

We have synthesized and characterized some novel Palladium allyl and 2-Meallyl complexes bearing hemilabile spectator ligands containing a pivoting carbene and a labile wing with pyridine nitrogen or thioetheric sulfur as coordinating atom. We have also synthesized and characterized some novel allyl and 2-Meallyl complexes bearing $\mathrm{PPh}_{3}$ and a hemilabile or monodentate carbene moiety as ligands. We have carried out the SC-XRD of the complexes 3a and $\mathbf{5 f}$. We have also studied the amination of the allyl coordinated to the selected complexes $\mathbf{2 a}$ and $\mathbf{2 c}$ by piperidine and, on the basis of experimental and computational results, we have confirmed that attack of the amine occurs trans to the carbene carbon irrespective of the hindrance of the substituent of the labile atom which however can heavily depress the reaction rate.

\section{Experimental}

\subsection{Solvents and reagents}

The solvents $\mathrm{CH}_{2} \mathrm{Cl}_{2}$ and $\mathrm{CH}_{3} \mathrm{CN}$ were distilled over $\mathrm{CaH}_{2}$, whereas all other solvents and chemicals were commercial grade products and used as purchased. 

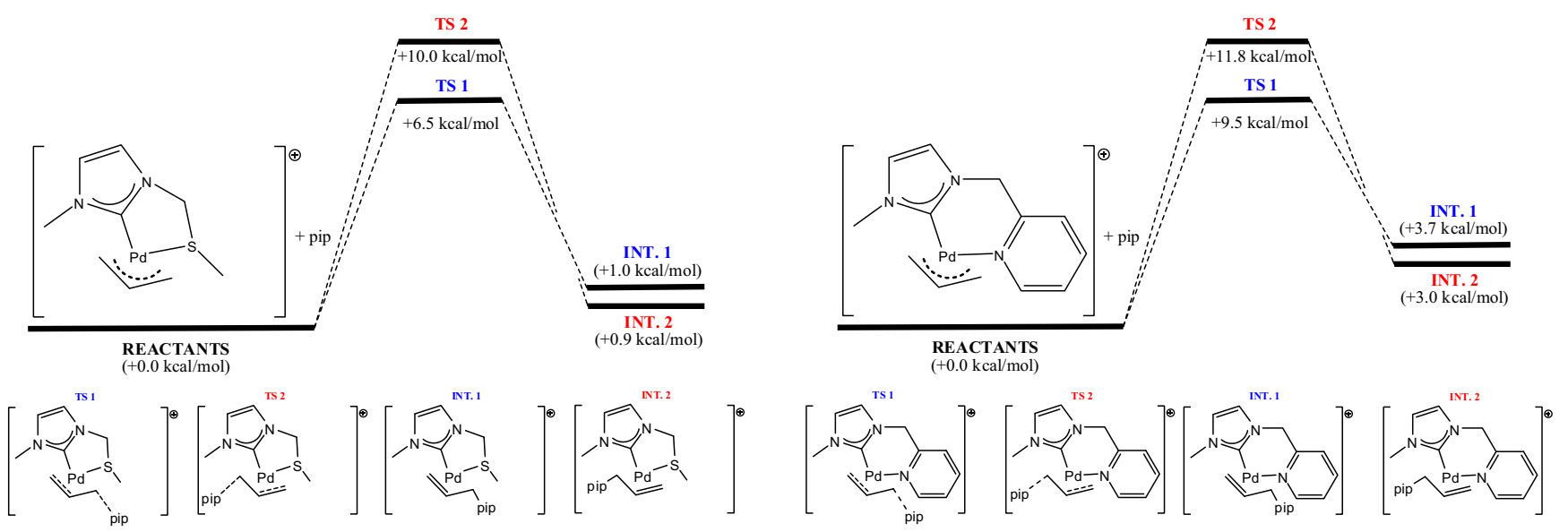

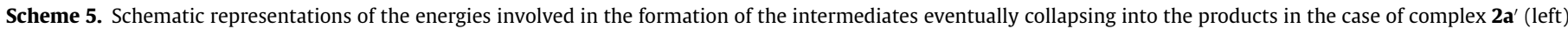
and $\mathbf{2} \mathbf{c}^{\prime}$ (right) reacting with piperidine.

\subsection{IR, NMR, UV-Vis measurements and elemental analysis}

The IR, ${ }^{1} \mathrm{H},{ }^{13} \mathrm{C}$ and ${ }^{31} \mathrm{P}$ NMR spectra were recorded on a PerkinElmer Spectrum One spectrophotometer and on a Bruker 300 Avance spectrometer, respectively.

The elemental analysis of the synthesized complexes was carried out using an Elementar CHN "CUBO micro Vario" analyzer.

\subsection{Kinetic measurements by ${ }^{1} H \mathrm{NMR}$}

The reactions between complexes $\mathbf{2 a}$ and $\mathbf{2} \mathbf{c}$ and piperidine were studied by ${ }^{1} \mathrm{H}$ NMR by dissolving the complex under study in $0.6 \mathrm{ml}$ of $\mathrm{CDCl}_{3}$ ([Complex $]_{0} \approx 2 \times 10^{-2} \mathrm{~mol} \mathrm{dm}^{-3}$ ), adding microaliquots of a concentrated $\mathrm{CDCl}_{3}$ solution of piperidine $\left([\right.$ Pip $] \approx 9.9 \times 10^{-2} \mathrm{~mol} \mathrm{dm}^{-3}$ ) in the presence of $\mathrm{dmfu}$ ( $[\mathrm{dmfu}] \approx 3 \times 10^{-2} \mathrm{~mol} \mathrm{dm}^{-3}$ ) and monitoring the signal for the disappearance of the starting complex (case of complex 2c) and the appearance of the final products (case of complex 2a).

\subsection{Data analysis}

Non linear regression analysis of the data related to kinetics measurements was performed by locally adapted routines written in the ORIGIN ${ }^{\circledR} 7.5$ environment.

\subsection{Crystal structure determinations}

The crystal data of compounds $\mathbf{3 a}$ and $\mathbf{5 f}$ were collected at room temperature using a Nonius Kappa CCD diffractometer with graphite monochromated Mo Ka radiation. The data sets were integrated with the Denzo-SMN package [22] and corrected for Lorentz, polarization and absorption effects (SORTAV) [23]. The structures were solved by direct methods using SIR97 [24] system of programs and refined using full-matrix least-squares with all non-hydrogen atoms anisotropically and hydrogens included on calculated positions, riding on their carrier atoms.

All calculations were performed using SHELXL-2014/16 [25] and PARST [26] implemented in WINGX [27] system of programs. The selection of bond distances and angles is given in Table 1SM whereas the crystal data are given in Table 2SM.

\subsection{Computational details}

As elsewhere stated, we have undertaken a detailed computational study in order to verify the consistency, if any, between a computational approach and our experimental observations in the case of the amination reaction of complexes $\mathbf{2} \mathbf{a}^{\prime}$ and $\mathbf{2} \mathbf{c}^{\prime}$.

Remarkably, our experimental results were in good agreement with the computational study carried out by the GAUSSIAN 09 program [28] and we have obtained a confirmation and hence a possible explanation of the observed reactivity trend.

The geometrical optimization of the complexes was carried out without symmetry constraints, using the hyper-GGA functional MO6 [29,30], in combination with polarized triple- $\zeta$-quality basis sets (LAN2TZ(f)) [31,32] and relativistic pseudopotential for the Pd atoms, and a polarized double- $\zeta$-quality basis sets $(6-31 \mathrm{G}(\mathrm{d}$, p)) for the other elements. Solvent effects $\left(\mathrm{CH}_{2} \mathrm{Cl}_{2}, \varepsilon=8.93\right)$ were included using CPCM [33,34].

The "restricted" formalism was applied in all the calculations. The zero-point vibrational energies and thermodynamic parameters were obtained [35] by means of the stationary points characterized by IR simulation.

All the computational work was carried out on Intel based x 86-64 workstations.

\subsection{Synthetic details}

As already stated, the ligands a [6v], b [14], c, d [15] and e [5h], the complexes 1a, 2a [16], 1b, 1c, 1d [14], the dimers $\left[\mathrm{Pd}(\mu-\mathrm{Cl})\left(\eta^{3}-\right.\right.$ $\left.\left.\mathrm{C}_{3} \mathrm{H}_{5}\right)\right]_{2}$ [17] and $\left[\mathrm{Pd}(\mu-\mathrm{Cl})\left(\eta^{3}-2-\mathrm{MeC}_{3} \mathrm{H}_{4}\right)\right]_{2}$ [18] are published species which were synthesized accordingly. The synthesis and characterization of all other compounds are reported in the following experimental part.

\subsection{Synthesis of the ligand Tol-Im-Tol $(\boldsymbol{f})$}

$3.647 \mathrm{~g}$ (21.0 mmol) of 1-(4-methylbenzyl)-1H-imidazole were dissolved in $50 \mathrm{ml}$ of anhydrous $\mathrm{CH}_{3} \mathrm{CN}$ in a two necked flask and $3.5 \mathrm{~g}(34.0 \mathrm{mmol})$ of $\mathrm{NaBr}$ and $3 \mathrm{ml}(23.0 \mathrm{mmol})$ of 1 -(chloromethyl)-4-methylbenzene were added in rapid sequence under inert atmosphere $(\mathrm{Ar})$. The resulting mixture was refluxed for $36 \mathrm{~h}$ and eventually the residual salts were filtered off and repeatedly washed with $\mathrm{CH}_{2} \mathrm{Cl}_{2}$ on a gooch. The clear solution was concentrated under vacuum and the title compound was precipitated as white powder by addition of diethylether. The compound was filtered off on a gooch, repeatedly washed with diethylether and dried under vacuum.

$6.62 \mathrm{~g}$ (yield $88 \%$ ) of the ligand were obtained. 
${ }^{1} \mathrm{H} \mathrm{NMR}\left(\mathrm{CDCl}_{3}, T=298 \mathrm{~K}, \mathrm{ppm}\right) \delta: 2.33\left(\mathrm{~s}, 3 \mathrm{H}\right.$, tol- $\left.\mathrm{CH}_{3}\right), 5.50(\mathrm{~s}$, $\left.2 \mathrm{H}, \mathrm{N}-\mathrm{CH}_{2}\right), 7.15(\mathrm{~d}, \mathrm{~J}=1.6 \mathrm{~Hz}, 2 \mathrm{H}, \mathrm{CH}=\mathrm{CH} \mathrm{Im}), 7.17-7.2(\mathrm{~m}, 2 \mathrm{H}$, $\mathrm{Ph}$ ), 7.33-7.36 (m, 2H, Ph), 10.98 (bt, 1H, NCHN).

${ }^{13} \mathrm{C}\left\{{ }^{1} \mathrm{H}\right\} \mathrm{NMR}\left(\mathrm{CDCl}_{3}, \mathrm{~T}=298 \mathrm{~K}, \mathrm{ppm}\right) \delta: 21.1\left(\mathrm{CH}_{3}, \mathrm{Ph}-\mathrm{CH}_{3}\right), 53.3$ $\left(\mathrm{CH}_{2}, \mathrm{~N}-\mathrm{CH}_{2}\right), 121.4(\mathrm{CH}, \mathrm{CH}=\mathrm{CH} \mathrm{Im}), 129.0(\mathrm{CH}, \mathrm{Tol} o-\mathrm{C}), 129.5$ (CH, Tol $i-\mathrm{C}), 130.0(\mathrm{CH}$, Tol $m-\mathrm{C}), 139.6(\mathrm{CH}, \mathrm{Tol} p-\mathrm{C}), 137.2(\mathrm{CH}$, NCHN).

IR ( $\mathrm{KBr}$ pellets): $v_{\mathrm{C}=\mathrm{N}}=1557 \mathrm{~cm}^{-1}$.

Anal. Calc. for $\mathrm{C}_{19} \mathrm{H}_{21} \mathrm{BrN}_{2}$ : C, 63.87; $\mathrm{H}, 5.92 ; \mathrm{N}, 7.84$. Found: $\mathrm{C}$, 63.99; $\mathrm{H}, 5.87$; N, 7.71\%.

\subsection{Synthesis of complex $\mathbf{1 f}$}

$0.400 \mathrm{~g}(1.12 \mathrm{mmol})$ of the ligand Tol-Im-Tol (f) was dissolved in $30 \mathrm{ml}$ of anhydrous $\mathrm{CH}_{2} \mathrm{Cl}_{2}$ in a two necked flask and $0.1557 \mathrm{~g}$ (0.672 mmol) of $\mathrm{Ag}_{2} \mathrm{O}$ was added under inert atmosphere (Ar). The mixture was stirred overnight at RT in the dark. The solution was filtered on millipore membrane filter, concentrated under vacuum and the title complex precipitated by addition of diethylether. The white complex was filtered off on a gooch, repeatedly washed with diethylether and $n$-pentane and dried under vacuum. $0.4893 \mathrm{~g}$ (yield $94 \%$ ) of complex was obtained.

${ }^{1} \mathrm{H} \mathrm{NMR}\left(\mathrm{CDCl}_{3}, T=298 \mathrm{~K}, \mathrm{ppm}\right) \delta: 2.35\left(\mathrm{~s}, 6 \mathrm{H}\right.$, tol- $\left.\mathrm{CH}_{3}\right), 5.25(\mathrm{~s}$, $\left.4 \mathrm{H}, \mathrm{N}-\mathrm{CH}_{2}\right), 6.90(\mathrm{~s}, 2 \mathrm{H}, \mathrm{CH}=\mathrm{CH} \mathrm{Im}), 7.16-7.17(\mathrm{~m}, 8 \mathrm{H}$, tol-H).

${ }^{13} \mathrm{C}\left\{{ }^{1} \mathrm{H}\right\}$ NMR $\left(\mathrm{CDCl}_{3}, \mathrm{~T}=298 \mathrm{~K}, \mathrm{ppm}\right) \delta: 21.1\left(\mathrm{CH}_{3}, \mathrm{Ph}-\mathrm{CH}_{3}\right), 55.5$ $\left(\mathrm{CH}_{2}, \mathrm{~N}-\mathrm{CH}_{2}\right), 121.2(\mathrm{CH}, \mathrm{CH}=\mathrm{CH} \mathrm{Im}), 127.8(\mathrm{CH}, \mathrm{Tol} o-\mathrm{C}), 129.7$ (CH, Tol m-C), 132.3 ( $\mathrm{CH}$, Tol $i-\mathrm{C}), 138.5$ (CH, Tol p-C), 180.8 (C, NCN).

Anal. Calc. for $\mathrm{C}_{19} \mathrm{H}_{20} \mathrm{AgBrN}_{2}$ : C, 49.17; $\mathrm{H}, 4.34 ; \mathrm{N}, 6.04$. Found: $\mathrm{C}$, 49.33; H, 4.19, N, 6.21\%.

\subsection{Synthesis of complex $\mathbf{2 b}$}

$0.0500 \mathrm{~g}(0.137 \mathrm{mmol})$ of the dimer $\left[\mathrm{Pd}(\mu-\mathrm{Cl})\left(\eta^{3}-\mathrm{C}_{3} \mathrm{H}_{5}\right)\right]_{2}$ was dissolved in ca. $10 \mathrm{ml}$ of anhydrous $\mathrm{CH}_{2} \mathrm{Cl}_{2}$ in a two necked flask and $0.1357 \mathrm{~g}(0.2735 \mathrm{mmol})$ of the silver complex $\mathbf{1 b}$ was added under inert atmosphere $(\mathrm{Ar})$ and the mixture was stirred at RT for ca. $30 \mathrm{~m}$. The precipitated $\mathrm{AgBr}$ was removed by filtration on a millipore membrane filter and $0.1040 \mathrm{~g}(0.7404 \mathrm{mmol})$ of $\mathrm{NaClO}_{4} \cdot \mathrm{H}_{2} \mathrm{O}$ dissolved in ca. $10 \mathrm{ml}$ of methanol $\left(\mathrm{CH}_{2} \mathrm{Cl}_{2} /\right.$ $\mathrm{MeOH} \approx 3 / 1$ ) was added to the clear solution. The mixture was stirred for ca. $15 \mathrm{~m}$, dried under vacuum and treated with $\mathrm{CH}_{2} \mathrm{Cl}_{2}$ and activated carbon. The inorganic salts were filtered off on a Celite filter and repeatedly washed with $\mathrm{CH}_{2} \mathrm{Cl}_{2}$, whereas the resulting solution was concentrated under vacuum. Addition of diethylether to the concentrated solution yields the precipitation of the complex $\mathbf{2 b}$ as a gummy white solid which was ground in diethylether and separated by evaporation to dryness of the supernatant under vacuum. $0.1407 \mathrm{~g}$ of $\mathbf{2 b}$ as a white microcrystalline solid was obtained (yield 93\%).

${ }^{1} \mathrm{H} \mathrm{NMR}\left(\mathrm{CDCl}_{3}, \mathrm{~T}=298 \mathrm{~K}, \mathrm{ppm}\right) \delta: 1.94\left(\mathrm{~s}, 3 \mathrm{H}, o\right.$-aryl- $\left.\mathrm{CH}_{3}\right), 2.04$ (s, 3H, o-aryl- $\left.\mathrm{CH}_{3}\right), 2.40$ (s, 3H, p-aryl- $\left.\mathrm{CH}_{3}\right), 2.43(\mathrm{~d}, J=15.9 \mathrm{~Hz}, 1 \mathrm{H}$, anti allyl-H trans-S), $3.00(\mathrm{~d}, J=6.9 \mathrm{~Hz}, 1 \mathrm{H}$, syn allyl-H trans-S), 3.09 (d, $J=13.71 \mathrm{H}$, anti allyl-H trans-C), 4.40 (d, $J=7.6 \mathrm{~Hz}, 1 \mathrm{H}$, syn allyl$\mathrm{H}$ trans $-\mathrm{C}$ ), $5.40(\mathrm{~m}, 1 \mathrm{H}$, central-allyl- $\mathrm{H}), 5.73,5.88$ (AB system, $J=13.6 \mathrm{~Hz}, 2 \mathrm{H}, \mathrm{CH}_{2} \mathrm{~S}$ ), 7.03 (bs, $2 \mathrm{H}, m$-aryl-H), 7.05 (d, $J=1.9 \mathrm{~Hz}$, $1 \mathrm{H}, \mathrm{CH}=\mathrm{CH} \mathrm{Im}), 7.37-7.47(\mathrm{~m}, 3 \mathrm{H}, \mathrm{Ph}), 7.54-7.60(\mathrm{~m}, 2 \mathrm{H}, \mathrm{Ph})$, $7.84(\mathrm{~d}, J=1.9 \mathrm{~Hz}, 1 \mathrm{H}, \mathrm{CH}=\mathrm{CH} \mathrm{Im})$.

${ }^{13} \mathrm{C}\{1 \mathrm{H}\}$ NMR $\left(\mathrm{CDCl}_{3}, T=298 \mathrm{~K}, \mathrm{ppm}\right) \delta: 17.6\left(\mathrm{CH}_{3}\right.$, o-mesityl$\left.\mathrm{CH}_{3}\right), 17.8\left(\mathrm{CH}_{3}\right.$, o-mesityl- $\left.\mathrm{CH}_{3}\right), 21.1\left(\mathrm{CH}_{3}, p\right.$-mesityl- $\left.\mathrm{CH}_{3}\right), 59.0$ $\left(\mathrm{CH}_{2}, \mathrm{CH}_{2}-\mathrm{S}\right), 59.2\left(\mathrm{CH}_{2}\right.$, allyl trans-S $), 69.9\left(\mathrm{CH}_{2}\right.$, allyl trans- $)$, $118.4(\mathrm{CH}$, central allyl $), 121.6(\mathrm{CH}, \mathrm{CH}=\mathrm{CH} \mathrm{Im}), 123.5(\mathrm{CH}, \mathrm{CH}=\mathrm{CH}$ Im), 129.0 ( $\mathrm{CH}, m$-mesityl), 129.2 ( $\mathrm{CH}, m$-mesityl), 130.1 ( $\mathrm{CH}, o-\mathrm{Ph})$, 130.3 (C, $i-\mathrm{Ph}), 130.5$ (CH, p-Ph), 132.1 (CH, m-Ph), 135.3 (C, o-mesityl), 135.7 (C, o-mesityl), 136.6 (C, $i$-Ph), 139.9 (C, p-mesityl), 180.7 (C, NHC).
IR [KBr Pellet]: $v_{\mathrm{ClO}}=1085, \delta_{\mathrm{ClO}}=620, \mathrm{~cm}^{-1}$.

Anal. Calc. for $\mathrm{C}_{22} \mathrm{H}_{25} \mathrm{~N}_{2} \mathrm{PdS}$ : C, 57.95; H, 5.53; N, 6.14. Found: C, $58.12 ; \mathrm{H}, 5.44, \mathrm{~N}, 6.02 \%$.

The synthesis of the complexes $\mathbf{2 c}, \mathbf{3 a}, \mathbf{3} \mathbf{b}$ and $\mathbf{3} \mathbf{c}$ was carried out following a procedure similar to that described for complex $\mathbf{2 b}$ using the appropriate allyl dimer and NHC silver complex. The different synthetic details will be specified where appropriate.

\subsection{Synthesis of complex $2 c$}

White microcrystalline powder. Yield $91 \%$.

In this case grinding in diethylether was unnecessary. The filtered-off complex was washed with $n$-pentane.

${ }^{1} \mathrm{H} \mathrm{NMR}\left(\mathrm{CDCl}_{3}, T=298 \mathrm{~K}, \mathrm{ppm}\right) \delta: 1.93(\mathrm{~d}, J=12.31 \mathrm{H}$, anti allyl$\mathrm{H}$ trans-N), 1.97 (s, 3H, o-aryl- $\left.\mathrm{CH}_{3}\right), 1.99\left(\mathrm{~s}, 3 \mathrm{H}, o\right.$-aryl- $\left.\mathrm{CH}_{3}\right), 2.39$ (s, $3 \mathrm{H}, p$-aryl- $\left.\mathrm{CH}_{3}\right), 2.91(\mathrm{~d}, J=6.9 \mathrm{~Hz}, 1 \mathrm{H}$, syn allyl-H trans-N), $3.44(\mathrm{~d}$, $J=13.7 \mathrm{~Hz}, 1 \mathrm{H}$, anti allyl-H trans-C), $4.29(\mathrm{~d}, J=7.7 \mathrm{~Hz}, 1 \mathrm{H}$, syn allyl-H trans-C), 5.40 (m, 1H, central-allyl-H), 5.47, 5.82 (AB system, $\left.J=15.2 \mathrm{~Hz}, 2 \mathrm{H}, \mathrm{CH}_{2} \mathrm{~N}\right), 6.94(\mathrm{~d}, J=1.9 \mathrm{~Hz}, 1 \mathrm{H}, \mathrm{CH}=\mathrm{CH} \mathrm{Im}), 7.01$ (bs, 2H, m-aryl-H),7.46 (ddd, $J=7.7,5.4,1.4 \mathrm{~Hz}, 1 \mathrm{H}, 5-\mathrm{Pyr}) ; 7.92$ (d, $J=1.9 \mathrm{~Hz}, 1 \mathrm{H}, \mathrm{CH}=\mathrm{CH} \mathrm{Im}), 8.02(\mathrm{td}, J=7.7,1.7 \mathrm{~Hz}, 1 \mathrm{H}, 4-\mathrm{Pyr})$, 8,19 (d, $J=7.7 \mathrm{~Hz}, 1 \mathrm{H}, 3-\mathrm{Pyr}$ ); 8.79 (d, $J=5.4 \mathrm{~Hz}, 1 \mathrm{H}, 6$-Pyr).

${ }^{13} \mathrm{C}\{1 \mathrm{H}\}$ NMR $\left(\mathrm{CDCl}_{3}, T=298 \mathrm{~K}, \mathrm{ppm}\right) \delta: 17.7\left(\mathrm{CH}_{3}, 0\right.$-mesityl$\left.\mathrm{CH}_{3}\right), 17.9\left(\mathrm{CH}_{3}\right.$, o-mesityl- $\left.\mathrm{CH}_{3}\right), 21.1\left(\mathrm{CH}_{3}, p\right.$-mesityl- $\left.\mathrm{CH}_{3}\right), 47.9$ $\left(\mathrm{CH}_{2}\right.$, allyl trans- $\left.\mathrm{N}\right), 54.7\left(\mathrm{CH}_{2}, \mathrm{CH}_{2}-\mathrm{Pyr}\right), 74.1\left(\mathrm{CH}_{2}\right.$, allyl trans- $\left.\mathrm{C}\right)$, 120.3 ( $\mathrm{CH}$, central allyl), $121.7(\mathrm{CH}, \mathrm{CH}=\mathrm{CH} \mathrm{Im}), 123.6(\mathrm{CH}, \mathrm{CH}=\mathrm{CH}$ Im), 125.3 ( $\mathrm{CH}, 5-\mathrm{Pyr}), 127.4$ (CH, 3-Pyr), 129.0 ( $\mathrm{CH}, m$-mesityl), 129.2 (CH, m-mesityl), 134.8 (C, o-mesityl), 135.2 (C, o-mesityl), 135.9 (C, i-mesityl), 139.7 (C, p-mesityl), 140.5 (CH, 4-Pyr), 153.8 (C, 2-Pyr), 155.6 (CH, 6-Pyr), 176.4 (C, NHC).

IR [KBr Pellet]: $v_{\mathrm{ClO}}=1090, \delta_{\mathrm{ClO}}=620, \mathrm{~cm}^{-1}$.

Anal. Calc. for $\mathrm{C}_{21} \mathrm{H}_{24} \mathrm{~N}_{3} \mathrm{Pd}$ : C, 59.37; H, 5.69; N, 9.89. Found: C, 59.49; H, 5.71; N 9.71\%.

\subsection{Synthesis of complex $\mathbf{3 a}$}

White microcrystalline powder. Yield 73\%.

In this case grinding in diethylether was unnecessary. The filtered-off complex was washed with $n$-pentane.

${ }^{1} \mathrm{H}$ NMR $\left(\mathrm{CDCl}_{3}, T=298 \mathrm{~K}, \mathrm{ppm}\right) \delta: 1.73\left(\mathrm{~s}, 3 \mathrm{H}\right.$, allyl- $\left.\mathrm{CH}_{3}\right), 1.95$ (s, 3H, o-aryl- $\left.\mathrm{CH}_{3}\right), 2.02\left(\mathrm{~s}, 3 \mathrm{H}, o\right.$-aryl- $\left.\mathrm{CH}_{3}\right), 2.36(\mathrm{~d}, J=1.9 \mathrm{~Hz}, 1 \mathrm{H}$, anti allyl-H trans-S), 2.41 (s, 3H, p-aryl- $\mathrm{CH}_{3}$ ), 2.56 (bt, syn allyl-H trans-S), $2.71\left(\mathrm{~s}, 3 \mathrm{H}, \mathrm{S}-\mathrm{CH}_{3}\right), 2.88(\mathrm{~s}, 1 \mathrm{H}$, anti allyl-H trans-C), 4.16 (d, $J=3.2 \mathrm{~Hz}, 1 \mathrm{H}$, syn allyl-H trans-C), 5.74 (bAB system, $2 \mathrm{H}$, $\left.\mathrm{CH}_{2} \mathrm{~N}\right), 7.08(\mathrm{~d}, J=1.9 \mathrm{~Hz}, 1 \mathrm{H}, \mathrm{CH}=\mathrm{CH} \mathrm{Im}), 7.04$ (bs, $1 \mathrm{H}$, $m$-aryl-H), 7.05 (bs, $1 \mathrm{H}, m$-aryl-H), $7.88(\mathrm{~d}, J=1.9 \mathrm{~Hz}, 1 \mathrm{H}, \mathrm{CH}=\mathrm{CH}$ Im).

${ }^{13} \mathrm{C}\{1 \mathrm{H}\}$ NMR $\left(\mathrm{CDCl}_{3}, T=298 \mathrm{~K}, \mathrm{ppm}\right) \delta: 17.6\left(\mathrm{CH}_{3}, o\right.$-mesityl$\left.\mathrm{CH}_{3}\right), 17.6\left(\mathrm{CH}_{3}\right.$, o-mesityl- $\left.\mathrm{CH}_{3}\right), 21.2\left(\mathrm{CH}_{3}, p\right.$-mesityl- $\left.\mathrm{CH}_{3}\right), 21.4$ $\left(\mathrm{CH}_{3}, \mathrm{~S}-\mathrm{CH}_{3}\right), 23.9\left(\mathrm{CH}_{3}\right.$, allyl- $\left.\mathrm{CH}_{3}\right), 56.4\left(\mathrm{CH}_{2}, \mathrm{CH}_{2}-\mathrm{S}\right), 59.4\left(\mathrm{CH}_{2}\right.$, allyl trans-S), $66.4\left(\mathrm{CH}_{2}\right.$, allyl trans- $), 121.9(\mathrm{CH}, \mathrm{CH}=\mathrm{CH} \mathrm{Im})$, $123.4(\mathrm{CH}, \mathrm{CH}=\mathrm{CH} \mathrm{Im}), 128.9(\mathrm{CH}, m$-mesityl $), 129.2(\mathrm{CH}, \mathrm{m}$-mesityl), 134.0 (C, central allyl), 134.7 (C, o-mesityl), 135.2 (C, o-mesityl), 136.8 (C, $i$-mesityl), 140.0 (C, p-mesityl), 180.8 (C, NHC).

IR [KBr Pellet]: $v_{\mathrm{ClO}}=1090, \delta_{\mathrm{ClO}}=620, \mathrm{~cm}^{-1}$.

Anal. Calc. for $\mathrm{C}_{18} \mathrm{H}_{25} \mathrm{~N}_{2} \mathrm{PdS}$ : C, 53.00; H, 6.18; N, 6.87. Found: C, 53.17; H, 6.04; N, 6.75\%.

\subsection{Synthesis of complex $\mathbf{3 b}$}

Pale yellow microcrystalline powder. Yield 95\%.

In this case grinding in diethylether was unnecessary. The filtered-off complex was washed with $n$-pentane.

${ }^{1} \mathrm{H} \mathrm{NMR}\left(\mathrm{CDCl}_{3}, T=298 \mathrm{~K}, \mathrm{ppm}\right) \delta: 1.69\left(\mathrm{~s}, 3 \mathrm{H}\right.$, allyl- $\left.\mathrm{CH}_{3}\right), 1.96$ $\left(\mathrm{s}, 3 \mathrm{H}, \mathrm{o}\right.$-aryl- $\left.\mathrm{CH}_{3}\right), 2.02\left(\mathrm{~s}, 3 \mathrm{H}, \mathrm{o}\right.$-aryl- $\left.\mathrm{CH}_{3}\right), 2.36(\mathrm{~d}, \mathrm{~J}=1.81 \mathrm{H}$, anti allyl-H trans-S), 2.41 (s, 3H, p-aryl- $\left.\mathrm{CH}_{3}\right), 2.75(\mathrm{t}, J=2.2 \mathrm{~Hz}, 1 \mathrm{H}$, syn 
allyl-H trans-S), 2.92 (s, anti allyl-H trans-C), $3.47\left(\mathrm{~s}, 3 \mathrm{H}, \mathrm{NCH}_{3}\right)$, $4.13(\mathrm{~d}, J=3.2 \mathrm{~Hz}, 1 \mathrm{H}$, syn allyl-H trans-C), 5.81, 5.84 (AB system, $J=13.7 \mathrm{~Hz}, 2 \mathrm{H}, \mathrm{CH}_{2} \mathrm{~S}$ ), 7.04 (bs, $2 \mathrm{H}, m$-aryl-H), 7.05 (d, $J=1.9 \mathrm{~Hz}$, $1 \mathrm{H}, \mathrm{CH}=\mathrm{CH} \mathrm{Im}), 7.36-7.46(\mathrm{~m}, 3 \mathrm{H}, \mathrm{Ph}), 7.54-7.58(\mathrm{~m}, 2 \mathrm{H}, \mathrm{Ph})$, $7.86(\mathrm{~d}, J=1.9 \mathrm{~Hz}, 1 \mathrm{H}, \mathrm{CH}=\mathrm{CH} \mathrm{Im})$.

${ }^{13} \mathrm{C}\{1 \mathrm{H}\}$ NMR $\left(\mathrm{CDCl}_{3}, T=298 \mathrm{~K}, \mathrm{ppm}\right) \delta: 17.7\left(\mathrm{CH}_{3}, 0\right.$-mesityl$\left.\mathrm{CH}_{3}\right), 17.7\left(\mathrm{CH}_{3}, o\right.$-mesityl- $\left.\mathrm{CH}_{3}\right), 21.2\left(\mathrm{CH}_{3}, p\right.$-mesityl- $\left.\mathrm{CH}_{3}\right), 23.6$ $\left(\mathrm{CH}_{3}\right.$, allyl- $\left.\mathrm{CH}_{3}\right), 59.2\left(\mathrm{CH}_{2}\right.$, allyl trans-S $), 59.4\left(\mathrm{CH}_{2}, \mathrm{CH}_{2}-\mathrm{S}\right), 67.9$ $\left(\mathrm{CH}_{2}\right.$, allyl trans-C), $121.8(\mathrm{CH}, \mathrm{CH}=\mathrm{CH} \mathrm{Im}), 123.5(\mathrm{CH}, \mathrm{CH}=\mathrm{CH}$ Im), 129.0 ( $\mathrm{CH}, m$-mesityl), 129.2 ( $\mathrm{CH}, m$-mesityl), 130.1 ( $\mathrm{CH}, o-$ $\mathrm{Ph}$ ), 130.4 (C, $i-\mathrm{Ph}), 130.6$ (CH, $p$-Ph), 132.0 (CH, m-Ph), 133.5 (C, central allyl), 134.9 (C, o-mesityl), 135.2 (C, o-mesityl), 136.7 (C, $i$-Ph), 139.9 (C, p-mesityl), 180.8 (C, NHC).

IR [KBr Pellet]: $v_{\mathrm{ClO}}=1088, \delta_{\mathrm{ClO}}=623, \mathrm{~cm}^{-1}$.

Anal. Calc. for $\mathrm{C}_{23} \mathrm{H}_{27} \mathrm{~N}_{2} \mathrm{PdS}$ : C, 58.78; H, 5.79; N, 5.96. Found: C, 58.93; H, 5.88; N, 5.84\%.

\subsection{Synthesis of complex $3 c$}

White microcrystalline powder. Yield $89 \%$.

In this case grinding in diethylether was unnecessary. The filtered-off complex was washed with $n$-pentane.

${ }^{1} \mathrm{H}$ NMR $\left(\mathrm{CDCl}_{3}, T=298 \mathrm{~K}, \mathrm{ppm}\right) \delta: 1.83\left(\mathrm{~s}, 3 \mathrm{H}\right.$, allyl- $\left.\mathrm{CH}_{3}\right), 1.92$ (d, $J=2.1 \mathrm{~Hz}, 1 \mathrm{H}$, anti allyl-H trans-N), $1.96\left(\mathrm{~s}, 3 \mathrm{H}, 0\right.$-aryl- $\left.\mathrm{CH}_{3}\right)$, $1.99\left(\mathrm{~s}, 3 \mathrm{H}, \quad 0\right.$-aryl-CH $\mathrm{CH}_{3}, 2.39(\mathrm{~s}, 3 \mathrm{H}, \quad$-aryl-CH3), $2.56(\mathrm{t}$, $J=2.6 \mathrm{~Hz}, 1 \mathrm{H}$, syn allyl-H trans-N), $3.29(\mathrm{~s}, 1 \mathrm{H}$, anti allyl-H transC), $4.01(\mathrm{~d}, J=3.0 \mathrm{~Hz}, 1 \mathrm{H}$, syn allyl-H trans-C), 5.52, 5.80 (AB system, $J=15.3 \mathrm{~Hz}, 2 \mathrm{H}, \mathrm{CH}_{2} \mathrm{~N}$ ), $6.93(\mathrm{~d}, J=1.8 \mathrm{~Hz}, 1 \mathrm{H}, \mathrm{CH}=\mathrm{CH} \mathrm{Im}), 7.01$ (bs, 2H, m-aryl-H), 7.44 (ddd, $J=7.7,5.3,1.5 \mathrm{~Hz}, 1 \mathrm{H}, 5-\mathrm{Pyr}$ ); 7.92 (d, $J=1.8 \mathrm{~Hz}, 1 \mathrm{H}, \mathrm{CH}=\mathrm{CH} \mathrm{Im}), 8.01(\mathrm{td}, J=7.7,1.7 \mathrm{~Hz}, 1 \mathrm{H}, 4-\mathrm{Pyr})$, $8,19$ (d, $J=7.7 \mathrm{~Hz}, 1 \mathrm{H}, 3-\mathrm{Pyr}) ; 8.76$ (d, $J=5.3 \mathrm{~Hz}, 1 \mathrm{H}, 6-\mathrm{Pyr}$ ).

${ }^{13} \mathrm{C}\{1 \mathrm{H}\} \mathrm{NMR}\left(\mathrm{CDCl}_{3}, T=298 \mathrm{~K}, \mathrm{ppm}\right) \delta: 17.8\left(\mathrm{CH}_{3}, o\right.$-mesityl$\left.\mathrm{CH}_{3}\right), 17.8\left(\mathrm{CH}_{3}\right.$, o-mesityl- $\left.\mathrm{CH}_{3}\right), 23.9\left(\mathrm{CH}_{3}\right.$, allyl- $\left.\mathrm{CH}_{3}\right), 21.1\left(\mathrm{CH}_{3}\right.$, p-mesityl- $\left.\mathrm{CH}_{3}\right), 48.1\left(\mathrm{CH}_{2}\right.$, allyl trans-N), $54.8\left(\mathrm{CH}_{2}, \mathrm{CH}_{2}-\mathrm{Pyr}\right)$, $72.0\left(\mathrm{CH}_{2}\right.$, allyl trans-C), $121.6(\mathrm{CH}, \mathrm{CH}=\mathrm{CH} \mathrm{Im}), 123.7(\mathrm{CH}, \mathrm{CH}=\mathrm{CH}$ Im), 125.2 (CH, 5-Pyr), 127.4 (CH, 3-Pyr), 129.0 (CH, m-mesityl), 129.1 (CH, m-mesityl), 134.9 (C, o-mesityl), 135.3 (C, o-mesityl), 135.3 (C, central allyl), 136.1 (C, i-mesityl), 139.6 (C, p-mesityl), 140.5 (CH, 4-Pyr), 153.9 (C, 2-Pyr), 155.6 (CH, 6-Pyr), 176.8 (C, $\mathrm{NHC})$.

IR [KBr Pellet]: $v_{\mathrm{ClO}}=1093, \delta_{\mathrm{ClO}}=620, \mathrm{~cm}^{-1}$.

Anal. Calc. for $\mathrm{C}_{22} \mathrm{H}_{26} \mathrm{~N}_{3} \mathrm{Pd}$ : C, 60.21; H, 5.97; N, 9.57. Found: C, 60.36 ; H, 6.11; N, 9.42\%.

\subsection{Synthesis of complex $\mathbf{4 e}$}

$0.0502 \mathrm{~g}(0.137 \mathrm{mmol})$ of the dimer $\left[\mathrm{Pd}(\mu-\mathrm{Cl})\left(\eta^{3}-\mathrm{C}_{3} \mathrm{H}_{5}\right)\right]_{2}$ was dissolved in ca. $10 \mathrm{ml}$ of anhydrous $\mathrm{CH}_{2} \mathrm{Cl}_{2}$ and $0.0986 \mathrm{~g}$ $(0.274 \mathrm{mmol})$ of the silver complex 1e dissolved in ca. $7 \mathrm{ml}$ of $\mathrm{CH}_{2} \mathrm{Cl}_{2}$ was added and the mixture was stirred at RT for ca. $30 \mathrm{~m}$. The precipitated $\mathrm{AgBr}$ was removed by filtration on a millipore membrane filter and $0.0718 \mathrm{~g}(0.274 \mathrm{mmol})$ of $\mathrm{PPh}_{3}$ was added to the clear solution which was left aside for ca. $15 \mathrm{~m}$. The resulting mixture was treated with $0.0800 \mathrm{~g}(0.570 \mathrm{mmol})$ of $\mathrm{NaClO}_{4} \cdot \mathrm{H}_{2} \mathrm{O}$ dissolved in ca. $8 \mathrm{ml}$ of methanol $\left(\mathrm{CH}_{2} \mathrm{Cl}_{2} / \mathrm{MeOH} \approx 2 / 1\right)$. and further stirred for ca. $15 \mathrm{~m}$, dried under vacuum and treated with $\mathrm{CH}_{2} \mathrm{Cl}_{2}$ and activated carbon. The inorganic salts were filtered off on a Celite filter and repeatedly washed with $\mathrm{CH}_{2} \mathrm{Cl}_{2}$, whereas the resulting solution was concentrated under vacuum. Addition of diethylether to the concentrated solution yields the precipitation of the complex $\mathbf{4 e}$ as a white solid which was filtered off on a gooch and washed with $n$-pentane. $0.1752 \mathrm{~g}$ of $4 \mathbf{e}$ was obtained (yield 94\%).

In this and in the cases of complexes $\mathbf{5 d}$ and $\mathbf{5 e}$ two isomers are detectable from the NMR spectra. (See also Section 2)

Most abundant isomer (ca. 55\%):
${ }^{1} \mathrm{H}$ NMR $\left(\mathrm{CDCl}_{3}, \mathrm{~T}=298 \mathrm{~K}, \mathrm{ppm}\right.$, selected peaks) $\delta: 3.08(\mathrm{~d}$, $J=13.4 \mathrm{~Hz}, 1 \mathrm{H}$, anti allyl-H trans-C), 3.31 (dd, $J=13.2,9.6 \mathrm{~Hz}, 1 \mathrm{H}$ anti allyl-H trans-P), $3.32\left(\mathrm{~s}, 3 \mathrm{H}, \mathrm{NCH}_{3}\right), 3.95-4.00(\mathrm{~m}, 2 \mathrm{H}$, syn allyl-H trans-P, syn allyl-H trans-C, partially overlapped), 4.60 (bs, 5.84, $\left.2 \mathrm{H}, \mathrm{NCH}_{2}\right), 5.28(\mathrm{~m}, 1 \mathrm{H}$, central-allyl-H).

${ }^{13} \mathrm{C}\{1 \mathrm{H}\}$ NMR $\left(\mathrm{CDCl}_{3}, T=298 \mathrm{~K}\right.$, ppm selected peaks) $\delta: 38.1$ $\left(\mathrm{CH}_{3}, \mathrm{NCH}_{3}\right), 54.3\left(\mathrm{CH}_{2}, \mathrm{NCH}_{2}\right), 67.4\left(\mathrm{~d}, \mathrm{CH}_{2}, J_{\mathrm{CP}}=30.0 \mathrm{~Hz}, \mathrm{CH}_{2}\right.$ allyl trans-P), $69.1\left(\mathrm{CH}_{2}\right.$, allyl trans-C), $121.0\left(\mathrm{~d}, \mathrm{CH}, J_{\mathrm{CP}}=5.0 \mathrm{~Hz}\right.$, central allyl), $123.1(\mathrm{CH}, \mathrm{CH}=\mathrm{CH} \mathrm{Im}), 123.4(\mathrm{CH}, \mathrm{CH}=\mathrm{CH} \mathrm{Im}), 176.4(\mathrm{~d}, \mathrm{C}$, $\left.J_{\mathrm{CP}}=19.5 \mathrm{~Hz}, \mathrm{NHC}\right)$.

${ }^{31} \mathrm{P}\{1 \mathrm{H}\}$ NMR $\left(\mathrm{CDCl}_{3}, T=298 \mathrm{~K} \delta: 26.1\right.$.

Less abundant isomer (ca. 45\%):

${ }^{1} \mathrm{H}$ NMR $\left(\mathrm{CDCl}_{3}, T=298 \mathrm{~K}, \mathrm{ppm}\right.$, selected peaks) $\delta: 2.51$ (dd, $J=13.2,10.2 \mathrm{~Hz}, 1 \mathrm{H}$, anti allyl-H trans-P), $2.84(\mathrm{~d}, J=13.5 \mathrm{~Hz}, 1 \mathrm{H}$ anti allyl-H trans-C), 3.95-4.00 ( $\mathrm{m}, 1 \mathrm{H}$, syn allyl-H trans-C, partially overlapped), 3.98 (dd, 6.9, $6.8 \mathrm{~Hz}, 1 \mathrm{H}$, syn allyl-H trans-P), 4.68, 4.80 (AB system, $\left.J=15.0 \mathrm{~Hz}, 2 \mathrm{H}, \mathrm{NCH}_{2}\right), 5.82(\mathrm{~m}, 1 \mathrm{H}$, central-allyl$\mathrm{H})$.

${ }^{13} \mathrm{C}\{1 \mathrm{H}\} \mathrm{NMR}\left(\mathrm{CDCl}_{3}, T=298 \mathrm{~K}, \mathrm{ppm}\right.$ selected peaks) $\delta: 38.0$ $\left(\mathrm{CH}_{3}, \mathrm{NCH}_{3}\right), 54.3\left(\mathrm{CH}_{2}, \mathrm{NCH}_{2}\right), 67.0\left(\mathrm{~d}, \mathrm{CH}_{2}, J_{\mathrm{CP}}=30.0 \mathrm{~Hz}, \mathrm{CH}_{2}\right.$ allyl trans-P), $68.9\left(\mathrm{CH}_{2}\right.$, allyl trans-C), $121.7\left(\mathrm{~d}, \mathrm{CH}, J_{\mathrm{CP}}=5.2 \mathrm{~Hz}\right.$, central allyl), $124.0(\mathrm{CH}, \mathrm{CH}=\mathrm{CH} \mathrm{Im}), 124.2(\mathrm{CH}, \mathrm{CH}=\mathrm{CH} \mathrm{Im}), 176.1(\mathrm{~d}, \mathrm{C}$, $\left.J_{\mathrm{CP}}=19.3 \mathrm{~Hz}, \mathrm{NHC}\right)$.

${ }^{31} \mathrm{P}\{1 \mathrm{H}\}$ NMR $\left(\mathrm{CDCl}_{3}, T=298 \mathrm{~K} \delta: 25.7\right.$.

IR [KBr Pellet]: $v_{\mathrm{ClO}}=1090, \delta_{\mathrm{ClO}}=623, \mathrm{~cm}^{-1}$.

Anal. Calc. for $\mathrm{C}_{32} \mathrm{H}_{32} \mathrm{~N}_{2} \mathrm{PPd}$ : C, 66.04; $\mathrm{H}, 5.54 ; \mathrm{N}, 4.81$. Found $\mathrm{C}$, 66.17; H, 5.66; N, 4.93\%.

The synthesis of the complexes $\mathbf{5 d}, \mathbf{5 e}, \mathbf{4 f}$ and $\mathbf{5 f}$ was carried out following a procedure similar to that described for complex $\mathbf{4 e}$ using the appropriate allyl dimer and NHC silver complex.

\subsection{Synthesis of complex $\mathbf{5 d}$}

White microcrystalline powder. Yield 93\%.

Most abundant isomer (ca. 55\%):

${ }^{1} \mathrm{H}$ NMR $\left(\mathrm{CDCl}_{3}, T=298 \mathrm{~K}, \mathrm{ppm}\right.$, selected peaks $) \delta: 1.73(\mathrm{~s}, 3 \mathrm{H}$, allyl- $\mathrm{CH}_{3}$ ), 2.68 (d, $J=10.1 \mathrm{~Hz}, 1 \mathrm{H}$, anti allyl-H trans-P), 2.67 (s, $1 \mathrm{H}$, anti allyl-H trans-C), $3.26\left(\mathrm{~s}, 3 \mathrm{H}, \mathrm{NCH}_{3}\right), 3.66(\mathrm{~s}, 1 \mathrm{H}$, syn allylH trans-C), 4.00 (bt, $1 \mathrm{H}$, syn allyl-H trans-P), 5.96, 5.05 (AB system, $\left.J=15.5 \mathrm{~Hz}, 2 \mathrm{H}, \mathrm{NCH}_{2}\right), 8.35$ (d, $J=4.0 \mathrm{~Hz}, 1 \mathrm{H}, 6$-Pyr).

${ }^{13} \mathrm{C}\{1 \mathrm{H}\}$ NMR $\left(\mathrm{CDCl}_{3}, T=298 \mathrm{~K}, \mathrm{ppm}\right.$ selected peaks $) \delta: 24.1$ $\left(\mathrm{CH}_{3}\right.$, allyl- $\left.\mathrm{CH}_{3}\right), 37.8\left(\mathrm{CH}_{3}, \mathrm{NCH}_{3}\right), 55.8\left(\mathrm{CH}_{2}, \mathrm{NCH}_{2}\right), 66.6\left(\mathrm{~d}, \mathrm{CH}_{2}\right.$, $J_{\mathrm{CP}}=31.6 \mathrm{~Hz}, \mathrm{CH}_{2}$ allyl trans-P), $68.8\left(\mathrm{CH}_{2}\right.$, allyl trans-C $), 123.2$ $(\mathrm{CH}, \mathrm{CH}=\mathrm{CH} \mathrm{Im}), 124.1(\mathrm{CH}, \mathrm{CH}=\mathrm{CH} \mathrm{Im}), 135.6(\mathrm{C}$, central allyl), 149.0 (C, 2-Pyr), 155.0 (CH, 6-Pyr), 177.3 (d, C, J

${ }^{31} \mathrm{P}\{1 \mathrm{H}\}$ NMR $\left(\mathrm{CDCl}_{3}, T=298 \mathrm{~K} \delta: 27.4\right.$.

Less abundant isomer (ca. 45\%):

${ }^{1} \mathrm{H}$ NMR $\left(\mathrm{CDCl}_{3}, T=298 \mathrm{~K}, \mathrm{ppm}\right.$, selected peaks $) \delta: 1.98(\mathrm{~s}, 3 \mathrm{H}$, allyl- $\left.\mathrm{CH}_{3}\right), 2.70(\mathrm{~s}, 1 \mathrm{H}$, anti allyl-H trans-C), $3.00(\mathrm{~d}, J=10.1 \mathrm{~Hz}$ $1 \mathrm{H}$, anti allyl-H trans-P), $3.50\left(\mathrm{~s}, 3 \mathrm{H}, \mathrm{NCH}_{3}\right), 3.73(\mathrm{~s}, 1 \mathrm{H}$, syn allyl$\mathrm{H}$ trans-C), 4.10 (bt, $1 \mathrm{H}$, syn allyl-H trans-P), 4.72, 5.05 (AB system, $\left.J=15.5 \mathrm{~Hz}, 2 \mathrm{H}, \mathrm{NCH}_{2}\right), 8.38$ (d, $\left.J=4.0 \mathrm{~Hz}, 1 \mathrm{H}, 6-\mathrm{Pyr}\right)$.

${ }^{13} \mathrm{C}\{1 \mathrm{H}\}$ NMR $\left(\mathrm{CDCl}_{3}, T=298 \mathrm{~K}, \mathrm{ppm}\right.$ selected peaks $) \delta: 23.6$ $\left(\mathrm{CH}_{3}\right.$, allyl- $\left.\mathrm{CH}_{3}\right), 37.9\left(\mathrm{CH}_{3}, \mathrm{NCH}_{3}\right), 55.6\left(\mathrm{CH}_{2}, \mathrm{NCH}_{2}\right), 66.6\left(\mathrm{~d}, \mathrm{CH}_{2}\right.$, $J_{\mathrm{CP}}=31.6 \mathrm{~Hz}, \mathrm{CH}_{2}$ allyl trans-P), $68.8\left(\mathrm{CH}_{2}\right.$, allyl trans-C), 123.8 $(\mathrm{CH}, \mathrm{CH}=\mathrm{CH} \mathrm{Im}), 124.4(\mathrm{CH}, \mathrm{CH}=\mathrm{CH} \mathrm{Im}), 135.6(\mathrm{C}$, central allyl $)$, 149.6 (C, 2-Pyr), 155.0 (CH, 6-Pyr), 177.0 (d, C, $J_{\mathrm{CP}}=18.8 \mathrm{~Hz}, \mathrm{NHC}$ ).

${ }^{31} \mathrm{P}\{1 \mathrm{H}\}$ NMR $\left(\mathrm{CDCl}_{3}, T=298 \mathrm{~K} \delta: 27.4\right.$

IR [KBr Pellet]: $v_{\mathrm{ClO}}=1093, \delta_{\mathrm{ClO}}=620, \mathrm{~cm}^{-1}$.

Anal. Calc. for $\mathrm{C}_{32} \mathrm{H}_{33} \mathrm{~N}_{3} \mathrm{PPd}$ : C, 64.38; H, 5.57; N, 7.04. Found: C, 64.49; H, 5.63; N, 6.87\%.

\subsection{Synthesis of complex $\mathbf{5 e}$}

White microcrystalline powder. Yield $91 \%$. Most abundant isomer (ca. 55\%): 
${ }^{1} \mathrm{H}$ NMR $\left(\mathrm{CDCl}_{3}, T=298 \mathrm{~K}, \mathrm{ppm}\right.$, selected peaks $) \delta: 1.66(\mathrm{~s}, 3 \mathrm{H}$, allyl- $\mathrm{CH}_{3}$ ), 2.40 (d, $J=10.1 \mathrm{~Hz}, 1 \mathrm{H}$, anti allyl-H trans-P), 3.01 (s, $1 \mathrm{H}$, anti allyl-H trans-C), $3.52\left(\mathrm{~s}, 3 \mathrm{H}, \mathrm{NCH}_{3}\right), 3.70(\mathrm{~s}, 1 \mathrm{H}$, syn allyl$\mathrm{H}$ trans-C), 3.97 (bt, $1 \mathrm{H}$, syn allyl-H trans-P), 4.51, 4.81 (AB system, $\left.J=15.3 \mathrm{~Hz}, 2 \mathrm{H}, \mathrm{NCH}_{2}\right)$.

${ }^{13} \mathrm{C}\{1 \mathrm{H}\} \mathrm{NMR}\left(\mathrm{CDCl}_{3}, \mathrm{~T}=298 \mathrm{~K}, \mathrm{ppm}\right.$ selected peaks) $\delta: 23.6$ $\left(\mathrm{CH}_{3}\right.$, allyl- $\left.\mathrm{CH}_{3}\right), 38.1\left(\mathrm{CH}_{3}, \mathrm{NCH}_{3}\right), 54.3\left(\mathrm{CH}_{2}, \mathrm{NCH}_{2}\right), 66.4\left(\mathrm{~d}, \mathrm{CH}_{2}\right.$, $J_{\mathrm{CP}}=31.0 \mathrm{~Hz}, \mathrm{CH}_{2}$ allyl trans-P), $68.8\left(\mathrm{CH}_{2}\right.$, allyl trans $\left.-\mathrm{C}\right), 122.9$ $(\mathrm{CH}, \mathrm{CH}=\mathrm{CH} \mathrm{Im}), 124.5(\mathrm{CH}, \mathrm{CH}=\mathrm{CH} \mathrm{Im}), 135.9\left(\mathrm{~d}, \mathrm{CH}, J_{\mathrm{CP}}=5.0 \mathrm{~Hz}\right.$, central allyl), $177.0\left(\mathrm{~d}, \mathrm{C}, J_{\mathrm{CP}}=19.0 \mathrm{~Hz}, \mathrm{NHC}\right)$.

${ }^{31} \mathrm{P}\{1 \mathrm{H}\}$ NMR $\left(\mathrm{CDCl}_{3}, T=298 \mathrm{~K} \delta: 27.8\right.$.

Less abundant isomer (ca. 45\%):

${ }^{1} \mathrm{H}$ NMR $\left(\mathrm{CDCl}_{3}, T=298 \mathrm{~K}, \mathrm{ppm}\right.$, selected peaks $) \delta: 2.00(\mathrm{~s}, 3 \mathrm{H}$, allyl- $\left.\mathrm{CH}_{3}\right), 2.81(\mathrm{~s}, 1 \mathrm{H}$, anti allyl-H trans-C), 3.29 (d, $J=10.6 \mathrm{~Hz}$, $1 \mathrm{H}$, anti allyl-H trans-P), $3.32\left(\mathrm{~s}, 3 \mathrm{H}, \mathrm{NCH}_{3}\right), 3.70(\mathrm{~s}, 1 \mathrm{H}$, syn allyl$\mathrm{H}$ trans-C), 4.07 (bt, $1 \mathrm{H}$, syn allyl-H trans- $\mathrm{P}$ ), 4.70, 4.80 (AB system, $\left.J=15.3 \mathrm{~Hz}, 2 \mathrm{H}, \mathrm{NCH}_{2}\right)$.

${ }^{13} \mathrm{C}\{1 \mathrm{H}\}$ NMR $\left(\mathrm{CDCl}_{3}, T=298 \mathrm{~K}, \mathrm{ppm}\right.$ selected peaks $) \delta: 24.0$ $\left(\mathrm{CH}_{3}\right.$, allyl- $\left.\mathrm{CH}_{3}\right), 38.1\left(\mathrm{CH}_{3}, \mathrm{NCH}_{3}\right), 54.0\left(\mathrm{CH}_{2}, \mathrm{NCH}_{2}\right), 66.0\left(\mathrm{~d}, \mathrm{CH}_{2}\right.$, $J_{\mathrm{CP}}=31.5 \mathrm{~Hz}, \mathrm{CH}_{2}$ allyl trans-P), $68.4\left(\mathrm{CH}_{2}\right.$, allyl trans-C $), 123.3$ $(\mathrm{CH}, \mathrm{CH}=\mathrm{CH} \mathrm{Im}), 124.5(\mathrm{CH}, \mathrm{CH}=\mathrm{CH} \mathrm{Im}), 135.6\left(\mathrm{~d}, \mathrm{C}, J_{\mathrm{CP}}=5.0 \mathrm{~Hz}\right.$, central allyl), 176.3 (d, C, $\left.J_{\mathrm{CP}}=19.0 \mathrm{~Hz}, \mathrm{NHC}\right)$.

${ }^{31} \mathrm{P}\{1 \mathrm{H}\}$ NMR $\left(\mathrm{CDCl}_{3}, T=298 \mathrm{~K} \delta: 27.5\right.$.

IR [KBr Pellet]: $v_{\mathrm{ClO}}=1093, \delta_{\mathrm{ClO}}=623, \mathrm{~cm}^{-1}$.

Anal. Calc. for $\mathrm{C}_{33} \mathrm{H}_{34} \mathrm{~N}_{2} \mathrm{PPd}$ : C, 66.50; H, 5.75; N, 4.70. Found: C, $66.37 ; \mathrm{H}, 5.91 ; \mathrm{N}, 4.63 \%$.

\subsection{Synthesis of complex $\mathbf{4 f}$}

White microcrystalline powder. Yield $87 \%$.

${ }^{1} \mathrm{H} \mathrm{NMR}\left(\mathrm{CDCl}_{3}, T=298 \mathrm{~K}, \mathrm{ppm}\right.$, selected peaks) $\delta: 2.30(\mathrm{~s}, 6 \mathrm{H}$, tol- $\mathrm{CH}_{3}$ ), 2.61 (dd, $J=13.3,10.5 \mathrm{~Hz}, 1 \mathrm{H}$, anti allyl-H trans-P), 2.85 (d, $J=13.4 \mathrm{~Hz}, 1 \mathrm{H}$, anti allyl-H trans-C), $3.99(\mathrm{~m}, 2 \mathrm{H}$, syn allyl- $\mathrm{H}$ trans-C, syn allyl-H trans-P), 4.59, 4.64 (AB system, $J=15.3 \mathrm{~Hz}$, $2 \mathrm{H}, \mathrm{NCH}_{2}$ ), 4.68, 4.84 (AB system, $\left.J=14.8 \mathrm{~Hz}, 2 \mathrm{H}, \mathrm{NCH}_{2}\right), 5.37$ (m, $1 \mathrm{H}$, central-allyl-H), 6.80-6.85 (m, $4 \mathrm{H}$, tol $o-\mathrm{H}), 7.02-7.17(\mathrm{~m}, 12$ $\mathrm{H}, \mathrm{CH}=\mathrm{CH} \mathrm{Im}, \mathrm{PPh}), 7.41-7.57$ ( $\mathrm{m}, 9 \mathrm{H}$, tol $m-\mathrm{H}, \mathrm{PPh})$.

${ }^{13} \mathrm{C}\{1 \mathrm{H}\}$ NMR $\left(\mathrm{CDCl}_{3}, T=298 \mathrm{~K}, \mathrm{ppm}\right.$ selected peaks $) \delta: 21.1$ $\left(\mathrm{CH}_{3}\right.$, tol- $\left.\mathrm{CH}_{3}\right), 54.4\left(\mathrm{CH}_{3}, \mathrm{NCH}_{2}\right), 54.5\left(\mathrm{CH}_{2}, \mathrm{NCH}_{2}\right), 67.9\left(\mathrm{~d}, \mathrm{CH}_{2}\right.$, $J_{\mathrm{CP}}=29.5 \mathrm{~Hz}, \mathrm{CH}_{2}$ allyl trans-P), $68.8\left(\mathrm{CH}_{2}\right.$, allyl trans- $\left.\mathrm{C}\right), 121.2(\mathrm{~d}$, $\mathrm{CH}, J_{\mathrm{CP}}=5.1 \mathrm{~Hz}$, central allyl), $123.2(\mathrm{CH}, \mathrm{CH}=\mathrm{CH} \mathrm{Im}), 123.6(\mathrm{CH}$, $\mathrm{CH}=\mathrm{CH} \mathrm{Im}), 176.1$ (d, C, $\left.J_{\mathrm{CP}}=19.0 \mathrm{~Hz}, \mathrm{NHC}\right)$.

${ }^{31} \mathrm{P}\{1 \mathrm{H}\} \mathrm{NMR}\left(\mathrm{CDCl}_{3}, T=298 \mathrm{~K} \delta: 25.8\right.$.

IR [KBr Pellet]: $v_{\mathrm{ClO}}=1090, \delta_{\mathrm{ClO}}=618, \mathrm{~cm}^{-1}$.

Anal. Calc. for $\mathrm{C}_{40} \mathrm{H}_{40} \mathrm{~N}_{2} \mathrm{PPd}$ : C, 70.02; H, 5.88; N, 4.08. Found: C, 69.97; H, 5.91; N, 3.87\%.

\subsection{Synthesis of complex $\mathbf{5 f}$}

White microcrystalline powder. Yield 91\%.

${ }^{1} \mathrm{H}$ NMR $\left(\mathrm{CDCl}_{3}, T=298 \mathrm{~K}\right.$, ppm, selected peaks) $\delta: 1.69(\mathrm{~s}, 3 \mathrm{H}$, allyl- $\left.\mathrm{CH}_{3}\right), 2.28\left(\mathrm{~s}, 3 \mathrm{H}\right.$, tol- $\left.\mathrm{CH}_{3}\right), 2.30\left(\mathrm{~s}, 3 \mathrm{H}\right.$, tol- $\left.\mathrm{CH}_{3}\right), 2.65$ (dd, $J=10.1,1.4 \mathrm{~Hz}, 1 \mathrm{H}$, anti allyl-H trans-P), $2.88(\mathrm{~s}, 1 \mathrm{H}$, anti allyl-H trans-C), 3.70 (s, 1H, syn allyl-H trans-C), 3.97 (bt, $1 \mathrm{H}$, syn allyl- $\mathrm{H}$ trans-P), 4.49, 4.83 (AB system, $J=15.1 \mathrm{~Hz}, 2 \mathrm{H}, \mathrm{NCH}_{2}$ ), 4.78, 4.94 (AB system, $\left.J=14.8 \mathrm{~Hz}, 2 \mathrm{H}, \mathrm{NCH}_{2}\right), 6.74-6.90(\mathrm{~m}, 4 \mathrm{H}$, tol $o-\mathrm{H})$, 7.00-7.15 (m, $12 \mathrm{H}, \mathrm{CH}=\mathrm{CH} \mathrm{Im}, \mathrm{PPh}), 7.40-7.57$ ( $\mathrm{m}, 9 \mathrm{H}$, tol $m-\mathrm{H}$, $\mathrm{PPh})$.

${ }^{13} \mathrm{C}\{1 \mathrm{H}\}$ NMR $\left(\mathrm{CDCl}_{3}, \mathrm{~T}=298 \mathrm{~K}, \mathrm{ppm}\right.$ selected peaks $) \delta: 21.0$ $\left(\mathrm{CH}_{3}\right.$, tol- $\left.\mathrm{CH}_{3}\right), 21.1\left(\mathrm{CH}_{3}\right.$, tol- $\left.\mathrm{CH}_{3}\right), 54.3\left(\mathrm{CH}_{3}, \mathrm{NCH}_{2}\right), 54.5\left(\mathrm{CH}_{2}\right.$, $\left.\mathrm{NCH}_{2}\right), 66.8\left(\mathrm{~d}, \mathrm{CH}_{2}, J_{\mathrm{CP}}=31.2 \mathrm{~Hz}, \mathrm{CH}_{2}\right.$ allyl trans-P), $68.5\left(\mathrm{CH}_{2}\right.$, allyl trans-C), $123.1(\mathrm{CH}, \mathrm{CH}=\mathrm{CH} \mathrm{Im}), 123.7(\mathrm{CH}, \mathrm{CH}=\mathrm{CH} \mathrm{Im}), 135.8(\mathrm{~d}$, C, $J_{\mathrm{CP}}=4.9 \mathrm{~Hz}$, central allyl), 176.6 (d, C, $J_{\mathrm{CP}}=18.5 \mathrm{~Hz}, \mathrm{NHC}$ ).

${ }^{31} \mathrm{P}\{1 \mathrm{H}\} \mathrm{NMR}\left(\mathrm{CDCl}_{3}, T=298 \mathrm{~K} \delta: 27.5\right.$.

IR [KBr Pellet]: $v_{\mathrm{ClO}}=1093, \delta_{\mathrm{ClO}}=620, \mathrm{~cm}^{-1}$.
Anal. Calc. for $\mathrm{C}_{41} \mathrm{H}_{42} \mathrm{~N}_{2} \mathrm{PPd}$ : C, 70.33; H, 6.05; N, 4.00. Found: C, $70.21 ; \mathrm{H}, 5.94 ; \mathrm{N}, 4.07 \%$.

\section{Appendix A. Supplementary data}

CCDC 1495383 and 1495384 contains the supplementary crystallographic data. These data can be obtained free of charge via http://www.ccdc.cam.ac.uk/conts/retrieving.html, or from the Cambridge Crystallographic Data Centre, 12 Union Road, Cambridge CB2 1EZ, UK; fax: (+44) 1223-336-033; or e-mail: deposit@ccdc.cam.ac.uk. Supplementary data associated with this article can be found, in the online version, at http://dx.doi.org/10. 1016/j.poly.2016.08.051.

\section{References}

[1] (a) H.W. Wanzlick, Angew. Chem., Int. Ed. 74 (1962) 129;

(b) H.W. Wanzlick, H.J. Kleiner, Angew. Chem., Int. Ed. 73 (1961) 493;

(c) H.W. Wanzlick, E. Schikora, Angew. Chem., Int. Ed. 72 (1960) 494:

(d) K. Öfele, J. Organomet. Chem. 12 (1968) 42.

[2] (a) A.J. Arduengo, R.L. Harllow, M.J. Kline, J. Am. Chem. Soc. 113 (1991) 361; (b) A.J. Arduengo, H.V.R. Dias, J.C. Calabrese, F. Davidson, J. Am. Chem. Soc. 114 (1992) 5530;

(c) A.J. Arduengo, H.V.R. Dias, J.C. Calabrese, F. Davidson, J. Am. Chem. Soc. 114 (1992) 9724.

[3] (a) D. Krishnan, M. Wu, M. Chiang, Y. Li, P.-H. Leung, S.A. Pullarkat, Organometallics 32 (2013) 2389;

(b) E.M. Prokopchuck, R.J. Puddhephatt, Organometallics 22 (2003) 563;

(c) T.M. Trnka, R.H. Grubbs, Acc. Chem. Res. 34 (2001) 18;

(d) T. Weskamp, V.P. Bohm, W.A. Hermann, J. Organomet. Chem. 600 (2000) 12 ;

(e) L. Jafapour, S.P. Nolan, Adv. Organomet. Chem. 46 (2000) 181.

[4] (a) D.S. McGuinness, W. Mueller, P. Wasserscheid, K.J. Cavell, B.W. Skelton, A. H. White, Organometallics 21 (2002) 175;

(b) D.J. Nielsen, K.J. Cavell, B.W. Skelton, A.H. White, Inorg. Chim. Acta 327 (2002) 116;

(c) R.E. Doutwhite, M. Green, P.J. Silkock, P.T. Gomes, J. Chem. Soc., Dalton Trans. (2002) 1386;

(d) W.A. Hermann, L.J. Goossen, M. Spiegler, Organometallics 17 (1998) 2162.

[5] (a) F. Visentin, A. Togni, Organometallics 26 (2007) 3746;

(b) A.W. Waltman, R.H. Grubbs, Organometallics 23 (2004) 3105;

(c) H. Seo, H. Park, B.Y. Kim, J.H. Lee, Y.K. Chung, Organometallics 22 (2003) 618;

(d) M. Freseth, A. Dhindsa, H. Røise, M. Tilset, J. Chem. Soc., Dalton Trans. (2003) 4516;

(e) L.G. Bonnet, R.E. Doutwhite, B.M. Kariuki, Organometallics 22 (2003) 4187; (f) A.A.D. Tulloch, S. Winston, A.A. Danoupolos, G. Eastham, M.B. Hursthouse, J. Chem. Soc., Dalton Trans. (2003) 699;

(g) A.A.D. Tulloch, A.A. Danoupolos, S. Khleinhenz, M.E. Light, M.B. Hursthouse, G. Eastham, Organometallics 20 (2000) 2027;

(h) A.A.D. Tulloch, A.A. Danoupolos, S. Winston, S. Khleinhenz, G. Eastham, J. Chem. Soc., Dalton Trans. (2000) 4499.

[6] (a) A. Bader, E. Lindner, Coord. Chem. Rev. 108 (1991) 27;

(b) C.S. Slone, D.A. Weinberger, C.A. Mirkin, Prog. Inorg. Chem. 48 (1999) 233;

(c) S.W. Kohl, L. Weiner, L. Schwartsburd, L. Konstantinovski, L.J.W. Shimon, Y. Ben-David, M.A. Iron, D. Milstein, Science 324 (2009) 74;

(d) M. Feller, E. Ben-Ari, M.A. Iron, Y. Diskin-Posner, G. Leitus, L.J.W. Shimon, L. Konstantinovski, D. Milstein, Inorg. Chem. 49 (2010) 1615;

(e) J.L. van der Vlugt, E.A. Pidko, D. Vogt, M. Lutz, A.L. Spek, Inorg. Chem. 48 (2009) 7513;

(f) J.I. van der Vlugt, M.A. Siegler, M. Janssen, D. Vogt, A.L. Spek, Organometallics 28 (2009) 7025;

(g) R. Lindner, B. van der Bosch, M. Lutz, J.N.H. Reek, J.I. van der Vlugt, Organometallics 30 (2011) 499;

(h) M.T. Whited, R.H. Grubbs, Acc. Chem. Res. 42 (2009) 1607;

(i) M. Gagliardo, N. Selander, N.C. Mehendale, G. van Koten, R.J.M. Klein Gebbink, K.J. Szabó, Chem. Eur. J. 14 (2008) 4800;

(j) I. Moreno, R. San Martin, B. Inés, M.T. Herrero, E. Dominguez, Curr. Org. Chem. 13 (2009) 878;

(k) D.M. Spasyuk, D. Zargarian, A. van der Est, Organometallics 28 (2009) 6531 ;

(l) S. Bonnet, J. Li, M.A. Siegler, L.S. von Chrzanowski, A.L. Spek, G. van Koten, R. J.M. Klein, Gebbink, Chem. Eur. J. 15 (2009) 3340;

(m) V.A. Kozlov, D.V. Aleksanyan, Y.V. Nelyubina, K.A. Lyssenko, A.A. Vasil'ev, P.V. Petrovski, I.L. Odinets, Organometallics 29 (2010) 2054;

(n) D.M. Spasyuk, D. Zargarian, Inorg. Chem. 49 (2010) 6203;

(o) J.-L. Niu, Q.-T. Chen, X.-Q. Hao, Q.-X. Zhao, J.-F. Gong, M.-P. Song, Organometallics 29 (2010) 2248;

(p) B.-S. Zang, W. Wang, D.D. Shao, X.-D. Hao, J.-F. Gong, M.-P. Song, Organometallics 29 (2010) 2579;

(q) M.A. Siegler, M. Lutz, A.L. Spek, R.J.M. Klein Gebbink, G. van Koten, Adv. 
Synth. Catal. 352 (2010) 2474;

(r) A. Ros, D. Monge, M. Alcarazo, E. Álvarez, J.M. Lassaletta, R.R. Fernàndez, Organometallics 25 (2006) 6039;

(s) S.J. Roseblade, A. Ros, D. Monge, M. Alcarazo, E. Álvarez, J.M. Lassaletta, R.R. Fernàndez, Organometallics 26 (2007) 2570;

(t) E. Kluser, A. Neels, M. Albrecht, Chem. Commun. (2006) 4495;

(u) J. Wolf, A. Labande, J.-C. Daran, R. Poli, Eur. J. Inorg. Chem. (2007) 5069;

(v) S.-T. Liu, C.-I. Lee, C.-F. Fu, C.-H. Chen, Y.-H. Liu, C.J. Elsevier, S.-M. Peng, J.-T. Chen, Organometallics 28 (2009) 6597:

(w) C. Fliedel, A. Sabbatini, P. Braunstein, Dalton Trans. 39 (2010) 8820.

[7] J.C. Jeffrey, T.B. Rauchfuss, Inorg. Chem. 18 (1979) 2658.

[8] P. Braunstein, F. Naud, Angew. Chem., Int. Ed. 40 (2001) 680.

[9] (a) S. Winston, N. Stylianides, A.A.D. Tulloch, J.A. Wright, A.A. Danopoulos, Polyhedron 23 (2004) 2813;

(b) X. Wang, S. Liu, G.-X. Jin, Organometallics 23 (2004) 6002;

(c) M. Yigit, B. Yigit, I. Ozdemir, E. Cetinkaya, B. Cetinkaya, Appl. Organomet. Chem. 20 (2006) 322;

(d) F. Zeng, Z. Yu, J. Org. Chem. 71 (2006) 5274;

(e) L. Mercs, G. Labat, A. Neels, A. Ehlers, M. Albrecht, Organometallics 25 (2006) 5648;

(f) Z. Xi, X. Zhang, W. Chen, S. Fu, D. Wang, Organometallics 27 (2007) 6636;

(g) Z. Xi, B. Liu, W. Chen, J. Org. Chem. 73 (2008) 3954;

(h) X. Zhang, Z. Xi, A. Liu, W. Chen, Organometallics 27 (2008) 4401;

(i) X. Zhang, B. Liu, A. Liu, W. Xie, W. Chen, Organometallics 28 (2009) 1336;

(j) Z. Xi, B. Liu, V. Lu, W. Chen, Dalton Trans. (2009) 7008;

(k) B. Liu, A. Liu, Y. Zhou, W. Chen, Organometallics 29 (2010) 1457;

(l) P.L. Chiu, C.-L. Lai, C.-F. Chang, C.-H. Hu, H.M. Lee, Organometallics 24 (2005) 6169;

(m) M.C. Jahnke, T. Pape, F.E. Hahn, Eur. J. Inorg. Chem. (2009) 1960.

[10] J. Tsuji (Ed.), Palladium Reagents and Catalysts Innovation in Organic Synthesis, Wiley, Chichester, UK, 1995, p. 290.

[11] (a) B. Crociani, S. Antonaroli, F. Di Bianca, L. Canovese, F. Visentin, P. Uguagliati, J. Chem. Soc., Dalton Trans. (1994) 1145;

(b) L. Canovese, F. Visentin, P. Uguagliati, F. Di Bianca, S. Antonaroli, B. Crociani, J. Chem. Soc., Dalton Trans. (1994) 3113;

(c) B. Crociani, S. Antonaroli, M. Paci, F. Di Bianca, L. Canovese, Organometallics 16 (1997) 384.

[12] (a) L. Canovese, F. Visentin, P. Uguagliati, G. Chessa, V. Lucchini, G. Bandoli, Inorg. Chim. Acta 275-276 (1998) 385;

(b) L. Canovese, F. Visentin, P. Uguagliati, G. Chessa, A. Pesce, J. Organomet. Chem. 566 (1998) 61;

(c) L. Canovese, F. Visentin, G. Chessa, A. Niero, P. Uguagliati, Inorg. Chim. Acta 293 (1999) 44:

(d) B. Crociani, S. Antonaroli, L. Canovese, F. Visentin, P. Uguagliati, Inorg. Chim. Acta 315 (2001) 172;

(e) L. Canovese, F. Visentin, C. Santo, G. Chessa, P. Uguagliati, Polyhedron 20 (2001) 3171;

(f) L. Canovese, G. Chessa, C. Santo, F. Visentin, P. Uguagliati, Organometallics 21 (2002) 4342;

(g) L. Canovese, G. Chessa, F. Visentin, P. Uguagliati, Coord. Chem. Rev. 248 (2004) 945; (h) B. Crociani, S. Antonaroli, G. Bandoli, L. Canovese, F. Visentin, P. Uguagliati, Organometallics 18 (1999) 1137

[13] (a) L. Canovese, F. Visentin, C. Santo, G. Chessa, V. Bertolasi, Organometallics 29 (2010) 3027;

(b) L. Canovese, F. Visentin, C. Levi, A. Dolmella, Dalton Trans. 40 (2011) 966.

[14] L. Canovese, F. Visentin, C. Levi, C. Santo, V. Bertolasi, Inorg. Chim. Acta 390 (2012) 105, and refs. therein.

[15] J. Liu, J. Chen, J. Zaho, Y. Zhao, H. Zhang, Synthesis (2003) 2661.

[16] L. Canovese, F. Visentin, C. Levi, C. Santo, V. Bertolasi, J. Organomet. Chem. 732 (2013) 27, and refs. therein.

[17] F.R. Hartley, S.R. Jones, J. Organomet. Chem. 66 (1974) 472.

[18] W.T. Dent, R. Long, A.J. Wilkinson, J. Chem. Soc. (1964) 1585.

[19] I.J.B. Lin, C.S. Vasam, Coord. Chem. Rev. 251 (2007) 642.

[20] B. Akermark, B. Krakenberger, S. Hansson, A. Vitagliano, Organometallics 6 (1987) 620

[21] M.N. Burnett, C.K. Johnson, ORTEP III, Report ORNL-6895, Oak Ridge National Laboratory, Oak Ridge, TN, 1996.

[22] Z. Otwinowski, W. Minor, in: C.W. Carter, R.M. Sweet (Eds.), Methods in Enzymology, vol. 276(Part A), Academic Press, London, 1997, pp. 307-326.

[23] R.H. Blessing, Acta Crystallogr., Sect A 51 (1995) 33.

[24] A. Altomare, M.C. Burla, M. Camalli, G.L. Cascarano, C. Giacovazzo, A. Guagliardi, A.G. Moliterni, G. Polidori, R. Spagna, J. Appl. Crystallogr. 32 (1999) 115.

[25] G.M. Sheldrick, Crystal Structure Refinement with SHeLxL, Acta. Crystallogr., Sect. C 71 (2015) 3.

[26] M. Nardelli, J. Appl. Crystallogr. 28 (1995) 659.

[27] L.J. Farrugia, J. Appl. Crystallogr. 32 (1999) 837.

[28] M.J. Frisch, G.W. Trucks, H.B. Schlegel, G.E. Scuseria, M.A. Robb, J.R. Cheeseman, G. Scalmani, V. Barone, B. Mennucci, G.A. Petersson, H. Nakatsuji, M. Caricato, X. Li, H.P. Hratchian, A.F. Izmaylov, J. Bloino, G. Zheng, J.L. Sonnenberg, M. Hada, M. Ehara, K. Toyota, R. Fukuda, J. Hasegawa, M. Ishida, T. Nakajima, Y. Honda, O. Kitao, H. Nakai, T. Vreven, J.A. Montgomery Jr., J.E. Peralta, F. Ogliaro, M. Bearpark, J.J. Heyd, E. Brothers, K.N. Kudin, V.N. Staroverov, R. Kobayashi, J. Normand, K. Raghavachari, A. Rendell, J.C. Burant, S.S. Iyengar, J. Tomasi, M. Cossi, N. Rega, J.M. Millam, M. Klene, J.E. Knox, J.B. Cross, V. Bakken, C. Adamo, J. Jaramillo, R. Gomperts, R.E. Stratmann, O. Yazyev, A.J. Austin, R. Cammi, C. Pomelli, J.W. Ochterski, R.L. Martin, K. Morokuma, V.G. Zakrzewski, G.A. Voth, P. Salvador, J.J. Dannenberg, S. Dapprich, A.D. Daniels, O. Farkas, J.B. Foresman, J.V. Ortiz, J. Cioslowski, D.J. Fox, Gaussian 09', Gaussian Inc., Wallingford, CT, 2009.

[29] Y. Zhao, D.G. Truhlar, Acc. Chem. Res. 41 (2008) 157.

[30] Y. Zhao, D.G. Truhlar, Theor. Chem. Acc. 120 (2008) 215.

[31] P.J. Hay, W.R. Wadt, J. Chem. Phys. 82 (270-283) (1985) 299.

[32] L.E. Roy, P.J. Hay, R.L. Martin, J. Chem. Theory Comput. 4 (2008) 1029.

[33] V. Barone, M. Cossi, J. Tomasi, J. Chem. Phys. 107 (1997) 3210.

[34] V. Barone, M. Cossi, J. Phys. Chem. A 102 (1998) 1995.

[35] (a) C.J. Cramer, Essentials of Computational Chemistry, second ed., Wiley, Chichester, 2004;

(b) F. Jensen, Introduction to Computational Chemistry, second ed., Wiley, Chichester, 2007. 